\title{
DISPUTES AND APPEALS: THE ARMED SERVICES BOARD OF CONTRACT APPEALS
}

\author{
JoEL P. SHEDd, JR.*
}

\section{I}

SCOPE

Several excellent articles have been written about the Armed Services Board of Contract Appeals (ASBCA), ${ }^{1}$ and it is not intended to repeat here what has been said before. The purpose of this article is to lay a foundation for the analysis and discussion of some of the current problems of contract appeals by presenting in proper perspective the limited but important role of ASBCA and boards of contract appeals in general in the totality of settling contract disputes. It is hoped that this article will serve to clarify and correct some rather common misconceptions about ASBCA and its procedures and jurisdiction.

Space limitation makes it impossible to present all the pertinent information, and in the selection of material the author has striven to make a balanced, unslanted presentation. He has expressed his own views, which no doubt have been colored by his service on ASBCA; and it would be surprising if they coincide in all respects with the official position of ASBCA and the Department of Defense.

II

Purpose of the Disputes Procedure

Despite continuing efforts to improve the drafting and administration of government procurement contracts, experience shows that numerous disputes inevitably will arise in the performance of such contracts. When military supplies and services are procured by contract, it is essential that the contract provide a means whereby the successful accomplishment of the military mission will not be frustrated by a dispute with the contractor, so that the government can obtain what it needs within the time

* A.B. I927, Emory University; LL.B. I933, Harvard University. Member, Armed Services Board of Contract Appeals since 1956. Member of the Georgia bar.

${ }^{2}$ The following articles were written by members of the Armed Services Board of Contract Appeals (ASBCA) and its predecessor Board: Smith, War Department Board of Contract Appeals, 5 FED. B. J. 74 (1943); Austin, Organization and Functions of the Armed Services Board of Contract Appeals, J.A.G. Bull. No. II (July, 1952); Cunco, Armed Services Board of Contract Appeals: Tyrant or Impartial Tribunal, 39 A.B.A.J. 373 (1953); Crawford, Disputes Under Government Contracts' Administrative Appellate lurisdiction, I Gov't Contract REv. 4 (I957); Spector, Anatomy of a Dispute, 20 FED. B. J. 398 (1960). See also Haas, An Appeal Board Views Contract Claims, r6 Fed. B. J. 40I (1956); Anderson, Disputes Article in Government Contracts, 44 MIch. L. Rev. 2II (I945); Joy, Disputes Clause in Government Contracts: $A$ Survey of Court and Administrative Decisions, 25 FordHAM L. REv. II (1956); Kennedy, Conclusiveness of Administrative Findings in Disputes Arising Under Government Contracts, 4 BAYLOR L. REv. I60 (1952); Braucher, Arbitration Under Government Contracts, I7 LAw \& Contensp. Prob. 473 (I952); Gubin, Disputes of Fact-Procedures Before the Armed Services Board of Contract Appeals, I2 FED. B. J. 321 (1952); Caruso, Federal Boards of Contract Appeals, 33 So. Carif. L. Rev. 403 (1960); Sass, A Government Lawyer Looks at the Contract Appeals System, 8 Catrolic U. L. Rev. 23 (1959). 
needed. The standard disputes clause, ${ }^{2}$ in conjunction with other standard contract clauses and particularly the changes clause, ${ }^{3}$ establishes a procedure to prevent disputes from disrupting performance by giving the government the contractual right to require the contractor to continue performance in the manner directed by the government. When there is a dispute over what is required by the specifications, it gives the government the right to require the contractor to perform in accordance with the government's interpretation no matter how reasonable the contractor's contrary interpretation may be, thus assuring that the dispute will not prevent the armed forces from receiving the kind of supplies needed within the time needed. In the absence of such a contract provision, the contractor could proceed with the manufacture of supplies conforming to his own interpretation of the specifications, even though such supplies might not meet the government's needs, or the contractor might discontinue performance entirely until the dispute was settled. If after award the government decides that it needs to change the specifications, it can require the contractor to manufacture the supplies in accordance with the change in specifications it has ordered, even though the contractor and the contracting officer are in sharp disagreement as to how much of a price adjustment the contractor should receive for the change.

The second major purpose served by the disputes clause is that it provides a means of settling disputes fairly and expeditiously without the expense of an action at law. When the government reserves the right to order the contractor to make changes and to proceed with performance in accordance with the government's interpretation, regardless of who is right, common fairness requires that the contract provide a means of compensating the contractor for work required by the government that is not covered by the contract price. It might be said that the disputes clause constitutes an agreement by the contractor to proceed as directed by the government in consideration of which the government agrees to pay the contractor an equitable adjustment in price, if the government's direction to proceed involves extra work not included in the contract price. However, the disputes clause is not limited to disputes which may hold up performance. Regardless of whether the dispute is of a nature that can hold up performance, it is advantageous both to the government and to the contractor that disputes be disposed of and that claims be settled and paid without the parties being subjected to the delay and expense of going to court.

It is essential to the efficient and economical accomplishment of the government's procurement functions that it have harmonious relations with its contractors ${ }^{4}$ and that it have a procedure for the settling of disputes that enjoys the confidence of contractors as being fair, speedy, and inexpensive. With the tremendous increase

'Armed Services Procurement Regulation (ASPR) 7-103.12, 32 C.F.R. $\$ 7.103-12$ (Supp. 1963).

${ }^{3}$ ASPR 7-103.2, 32 C.F.R. \$7.103-2 (Supp. I963) (supply); ASPR 7-602.3, 32 C.F.R. \$7.602-3 (Supp. I963) (construction).

Hearings Before the Subcommittee for Special Investigations of the House Armed Services Committee Under H. Res. 67, Inquiry Into the Administration and Operations of the Armed Services Board of Contract Appeals, 85th Cong., 2d Sess. 796-97, 819 (1958). 
in the dollar volume of procurement contracts during and since World War II, a contractor could easily be thrown into bankruptcy by delay in payment over a dispute; and it is little consolation to such a contractor to know that years later his trustee in bankruptcy will obtain a judgment against the government in an action at law.

An essential element of a satisfactory dispute procedure is that an aggrieved contractor can appeal to the department head or his authorized representative or board and obtain full and impartial consideration and decision of the matter in dispute..$^{\bar{J}}$ Such a procedure has been established in the defense establishment through ASBCA, which has been designated as the authorized representative of the Secretary of Defense and the secretaries of the three military departments (Army, Navy, and Air Force) for considering and determining contract appeals as fully and finally as might each of the secretaries. ${ }^{6}$ At present there are eleven boards of contract appeals in the various departments and agencies engaged in procurement of supplies and services by contract. ${ }^{7}$ ASBCA is the oldest and by far the largest of the boards of contract appeals, and the other boards are modeled after it in varying degrees. This article is confined largely to ASBCA, because of the author's greater familiarity with it, but the same principles apply to all the boards.

That ASBCA has successfully accomplished its intended purposes is attested by numerous statements made during the past twenty years by representatives of industry groups and bar associations, ${ }^{8}$ but the real proof of the pudding is in the eating. A $195^{8}$ study shows that only one contract transaction out of I0,000 resulted in an appeal. ${ }^{9}$ In excess of ninety-five per cent of the disputes appealed to ASBCA are finally disposed of without any court action, despite the fact that ASBCA has dismissed a substantial number of appeals for lack of jurisdiction. ${ }^{10}$ The enormous increase in the number, dollar amounts, and complexity of military procurement contracts since pre-World War II days has not produced any substantial increase in the number of contract cases in the Court of Claims. In recent years the average time taken to dispose of an appeal from date of docketing to date of final decision has been approximately eleven months, which is years less than the average time required to obtain a decision in an action at law. ${ }^{11}$ The Department of Defense policy of attempting to "wash its own dirty linen" and dispose of contract disputes without resort to court action is consistent with the modern trend in commercial transactions, and it is believed that the defense establishment's record of settlement without resort to law compares favorably with that of private business.

${ }^{5}$ Id. at $794,8 \mathrm{I} 8$.

- ASBCA revised charter effective May I, I962, ASPR App. A, Part I, 27 Fed. Reg. 6r39 (I962).

7 Administrative Conference of the United States, Statistical Data Relating to Administrative Proceedings Conducted by Federal Agencies, Classified Index 78-79 (1962).

${ }^{8}$ See, e.g., Report of the Committee on Public Contracts, Administrative Law Section, District of Columbia Bar Ass'n, in Hearings, supra note 4, at 86r-63.

${ }^{\circ}$ Id. at $8 \mathrm{r} 6$.

${ }^{10} \mathrm{Id}$. at $8 \mathrm{rg}$.

${ }^{11}$ Id. at 858 . 
III

\section{Historical Development}

\section{A. Authority of Executive Department Head to Appoint an Adjudicatory Board}

The first case on the authority of the head of an executive department to appoint a board to hear and decide contract claims was United States $v$. Adams, ${ }^{12}$ decided by the Supreme Court in I868, which involved contracts awarded to Adams by the chief quartermaster of the Western Military District under which he built and delivered to the Army a number of boats. As a result of frauds against the government committed by the chief quartermaster (for which he was later dishonorably discharged from the service), the Secretary of War suspended payments on all his contracts until an investigation could be made; and on October 25, 186I he appointed a board of three commissioners to go to the Western Military District and examine and report to him on all claims where payment had been suspended. The Board promptly went to St. Louis and issued a notice calling on all claimants to present their claims with proofs. Adams presented claims showing a balance due of $\$ 209,000$, of which amount the board allowed $\$ 96,000$, for which Adams presented vouchers and received payment. Thereafter Adams filed suit in the Court of Claims and obtained judgment for the unpaid balance of the stated contract prices. ${ }^{13}$ The Supreme Court reversed the Court of Claims and dismissed the petition.

It was argued that the Secretary of War had no authority to appoint a board to hear and decide claims, but the Supreme Court found such authority in his general statutory authority to administer the War Department. It said that the Secretary had the duty to see that War Department contracts were faithfully executed, whether such contracts were made by himself or under authority conferred by him on others; that when he had well-grounded suspicions of fraud, he had the right and the duty to suspend payments; that where the contracts were made and performed distant from Washington and so resort to the Court of Claims or Congress for relief would occasion delay and expense, it was reasonable for the Secretary to appoint a board to meet at once at the place where all the transactions had occurred, so as to afford the claimants a tribunal for the speedy hearing and deciding of their claims without the delay and expense of going to law; that, while the claimants were under no obligation to present their claims to the board and the board had no authority to hear and decide a claim without the consent of the claimant, when claimants voluntarily presented their claims to the board and presented vouchers for, and accepted payment of, the amount found due by the board, they became bound by its decision. The significance of the case is its holding that the head of an executive department, as an incident of his general authority to administer his department, has authority to do what in his judgment is necessary for the protection of the interests of the government and the efficient discharge of the functions of his department, including the appointment of a board to hear and decide contract claims

${ }^{12} 74$ U.S. ( 7 Wall.) 463 (I868).

${ }^{18}$ Adams v. United States, 2 Ct. Cl. 70 (1866). 
where justified by the circumstances, but that the claimant-contractor is not bound by a decision of a board so appointed unless he had consented to be so bound.

This broad concept of the authority of the head of an executive department with respect to the contracts of his department is in conformity with the Supreme Court's decision in United States v. Corliss Steam-Engine Co., ${ }^{14}$ decided in I875, wherein the Court held that the general act creating the Navy Department gave the Secretary of the Navy authority to breach a contract by terminating it when in the public interest to do so and to enter into an agreement with the contractor for the settlement of his claim for unliquidated damages for breach of contract. The present boards of contract appeals appointed by the heads of the various executive departments and agencies do not have any specific statutory basis other than the general authority of the department head, any more than did the board appointed by the Secretary of War in $186 .{ }^{15}$ However, the consent of the contractor to be bound by the board's decision is spelled out contractually in the standard disputes clause.

\section{B. Legality of Finality Clauses}

The earliest Supreme Court decision on the validity of a "finality" clause in a government contract is Kihlberg $v$. United States ${ }^{16}$ decided in 1878, which involved a contract for the transportation of Army supplies with payment to be based on distance, "the distance to be ascertained and fixed by the chief Quartermaster of the district of New Mexico." The contractor complained that the distance fixed by the chief quartermaster was less than the air line distance. In holding that for contract payment purposes the contractor was bound by the distance determined by the quartermaster, the Court said that the contract clause clearly expressed a mutual intent to make the determination of the designated official conclusive, that there was neither allegation nor proof of bad faith on his part, and that the difference between his estimate and the air line distance was "not so material as to justify the inference that he did not exercise the authority given him with an honest purpose to carry out the real intention of the parties."17

Kihlberg was nothing more than the application to a government contract of what was then, and still is, a well-established principle of the law of private contracts, namely, that the parties to a contract can agree to be bound by the decision of a designated person with respect to a matter arising under the contract. The law as to private contracts is that when the parties include in their contract a finality clause clearly expressing an intention to be bound by the decision of a designated person on a specified matter, they are bound by the designated person's decision, if he makes his decision honestly as contemplated by the contract. ${ }^{18}$ The approach of the courts is that it is simply a matter of giving effect to the intention of the parties as

${ }^{14} 9$ I U.S. 321 (1875).

15 AdMinistrative Conference of the UNITED STATEs, op. cit. supra note 7.

${ }_{10}^{10} 97$ U.S. 398 (1878).

${ }^{17}$ Id. at $40 \mathrm{I}$.

${ }^{18} 3$ Samuel Williston, Contracts $\$ \$ 794-803$ (I936); 3A Arthur L. Corbin, Contracts $\$ 652$ (1960); I2 AM. JuR. Contracts $\$ 342$ (1938). 
expressed in their contract. The very object of such contract provisions is to preclude contentions and avoid litigation; hence, nothing short of fraud or mala fides will dispense with compliance with such a contract condition. ${ }^{10}$ A common type of finality clause used in commercial transactions is the type of provision commonly found in construction contracts under which the amount, classification, sufficiency, completion, and so on, of work done by the contractor shall be determined by a supervising architect, or other person designated in the contract; and such provisions have been held valid and effective, notwithstanding the architect's interest in the dispute, as where the dispute is over the correctness and adequacy of the plans and specifications prepared for the owner by the architect or where the architect is the agent or employee of one of the parties. ${ }^{20}$ Professor Williston has included cases involving government contract finality clauses under the general classification of cases giving conclusiveness to architect's certificates. ${ }^{21}$

Consistently since Kihlberg the Supreme Court has upheld as conclusive on both parties decisions made under finality clauses of government contracts by applying to such contracts the same principles as are applied to contracts between private persons. Decisions under finality clauses of government contracts have been upheld, regardless of whether the decision was on a simple question of fact, such as the mileage between two points, or a decision calling for the application of expert knowledge and experience, such as an appraisal or accounting determination, or a complicated mixed question of law and facts, such as the interpretation of contract specifications. Before any appeal boards were ever established, the Supreme Court upheld decisions under finality clauses regardless of whether made on-the-spot by the government officer directly involved in the dispute without any right of appeal or made by a higher level review or appellate authority. The conclusive effect of such decisions did not turn on the independence, impartiality or disinterestedness of the government officer who made the decision, the opportunity of the contractor to present evidence in support of his position, or what evidence the officer making the decision had to support his decision.

The reported cases show appearing in government contracts with increasing frequency prior to World War I provisions for appeal to the department head from an adverse decision of the local officer involved in the day-to-day administration of the contract; but there is no indication that the inclusion of appeal and review provisions was due to any prodding from the courts or Congress. The Supreme Court has indicated a willingness to give effect to clauses which extend finality much further than the executive departments have generally wanted to go.

\section{World War I Boards}

Although it was not unusual for pre-World War I finality clauses to give the contractor the right to appeal to the department head, no department had developed

${ }_{10}^{12}$ AM. JUR. Contracts $\$ 342$ (1938).

${ }^{20}$ Supra note 18; Annot., 54 A.L.R. I255 (1928); Annot., I10 A.L.R. 137 (1938).

${ }^{22} 3$ SAMuel WiLliston, Contracts $\$ 798$ n.2 (1936). 
a formal appeal procedure. The first time an executive department established anything in the nature of a board of contract appeals to hear and decide appeals was by the War Department during World War I. On September 7, I9I8 the War Department promulgated a standard form contract, including a clause entitled "Adjustment of Claims and Disputes," providing: ${ }^{22}$

Except as otherwise specifically provided in this contract, any claims, doubts, or disputes which may arise under this contract, or as to its performance or nonperformance, and which are not disposed of by mutual agreement, may be determined, upon petition of the contractor, by the Secretary of War or his duly authorized representative or representatives. If the Secretary of War selects a board as his authorized representative to hear and determine any such claims, doubts, or disputes, the decision of the majority of said board shall be deemed to be the decision of the board. The decision of the Secretary of War or of such duly authorized representative or representatives shall be final and conclusive on all matters submitted for determination. ...

The above-quoted clause was an optional all-disputes finality clause under which no finality attached to any decision unless the contractor elected to appeal to the Secretary of War on a matter not disposed of by mutual agreement. When the contractor exercised his election to appeal to the Secretary, the decision of the Secretary or his authorized representative was "final and conclusive."

The War Department Board of Contract Adjustment was established by order of the Secretary of War on November $6, \mathrm{rg}_{1} 8^{23}$ to meet the requirements for a board that would perform the functions provided for in the above-quoted clause. It was intended that the Board relieve the Secretary of War of the determination of many perplexing questions which would otherwise be submitted to him. The plan was to have it composed of outstanding men drawn from civil life whose views would command the confidence of contractors and make them feel that their rights were being considered in a broad and business-like fashion by men accustomed to deal with similar important questions. As originally constituted, the Board was composed of eminent lawyers who were recruited from civilian status and commissioned in the Army. As the workload of the Board increased, it was expanded, and civilian attorneys were added as board members. ${ }^{24}$ In August rgrg the Board had twenty-two members, consisting of seven army officers and fifteen civilian attorneys. ${ }^{25}$ The salary paid civilian members was $\$ 7,500$ per year, ${ }^{26}$ which was a high government salary for that time, when it is recalled that at that time the annual

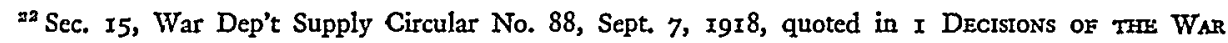
Dep't Board of Contract AdjustMent at xxxviii [hereinafter cited as Dec. WDBC ADJ.]

${ }^{23}$ War Dep't Gen. Order No. I03, Nov. 6, I9I8.

${ }^{24}$ Delafield, Jurisdiction of the Secretary of War to Settle Contracts, and Over Claims, Doubts and Disputes Arising Out of War Department Contracts Whether During Performance or Upon Suspension or Termination, I DEc. WDBC ADJ. at xxxi (I919); Wise, Board of Contract Adjustment of the War Department, 6 VA. L. Rev. I82 (1919). General Delafield was chairman and Mr. Wise was a member of the War Department Board of Contract Adjustment.

${ }^{35}$ I DEC. WDBC ADJ. iii (rgrg).

${ }^{20}$ Wise, supra note 24. 
salary of judges of the Court of Claims was $\$ 6,000$, of U.S. Senators and Congressmen, $\$ 7,500$; and of Cabinet Members, $\$ \mathrm{r} 2,000{ }^{27}$

The order of the Secretary creating the Board authorized it "to hear and determine all claims, doubts or disputes, including all questions of performance or nonperformance which may arise under any contract made by the War Department." The Board was authorized to adopt its own rules, and under its Rules of Procedure the parties were given the right to be heard and introduce evidence. Hearings were conducted in a manner similar to a trial in a court of record with a verbatim transcript of the hearing.

The Board did not start functioning until after the flood of contract terminations brought about by the Armistice, and it was assigned to hear and decide termination settlements where the contractor was not satisfied with the determination of the contracting officer or bureau chief..$^{28}$ After the passage of the Dent Act, ${ }^{20}$ it was given original jursdiction to decide "implied contract" claims coming within the purview of that act. ${ }^{30}$ In June I920, it was merged with, and made the Appeal Section of the War Department Claims Board ${ }^{31}$ that had been established to liquidate the more than 30,000 war claims coming within the cognizance of the War Department. $^{32}$ With the completion of the war claims settlement program, the War Department Claims Board was dissolved by order dated February $28,1922,{ }^{38}$ and its powers and duties to hear and determine claims, doubts and disputes were transferred to the Assistant Secretary of War.

During the period from January 22, IgI9 to July 29, I92I the Board of Contract Adjustment and its successor, the Appeal Section of the War Department Claims Board, disposed of 3,06r cases, with some 2,700 decisions; and its written decisions, with headnotes and index-digest prepared by the Board's professional staff, were published by the Government Printing Office in eight bound volumes. ${ }^{34}$ The Board drew high praise from Professor Wigmore when he said that "its volumes of opinions expounding the findings of fact and law are models of clarity and directness-refreshing in their contrast to the futile display of technique upon Evidence rules so often seen in the opinions of Supreme Courts upon everyday cases of mercantile disputes over broken contracts." ${ }^{35}$

The Secretary of the Navy also found it necessary during World War I to establish a board to consider disputes between contractors and the bureaus, so that the Secretary might be "relieved of conducting interviews and hearings which were

${ }^{27}$ Act of Feb. 26, 1907, § 4, 34 Stat. 993.

${ }^{28}$ War Dep't Supply Cir. No. IIx, Nov. 9, Igx8, quoted in I Dec. WDBC ADj. xliii (rg19); Delafield, supra note 24.

${ }^{29}$ Act of March 2, I919, 40 Stat. I272.

${ }^{30}$ War Dep't Supply Cir. No. 77 , March 26, 1919, quoted in I Dec. WDBC Ady. at xlvi (1919).

${ }^{31}$ War Dep't Gen. Order No. 40, June 26, rg20.

${ }^{32} 65$ Conc. Rec. 1385 (1924), and H.R. Doc. No. 364 , 68th Cong., 2d Sess. (1924).

${ }^{88}$ War Dep't Gen. Order No. 9, Feb. 28, 1922.

sc 8 Dec. WDBC Adj. at lv (I92I); 9 Wirliston on Contracts (T. W. Graske, The Law Govennino tHe SETTLEMENT OF WAR CoNTract Claims) \& 1 n.I (rev. ed. 1945).

${ }^{36}$ I JOHN H. Wigmore, EVIDENCE $\$ 4$ (c), at 74 (3d ed. 1940). 
taking considerable of his time and patience."36 $\mathrm{He}$ considered it essential that such disputes be reviewed and an equitable settlement recommended by a board that was independent of the bureaus, for the protection of both parties to the contract. The immediate need for the board grew out of the allowability of costs under cost-plus contracts for the construction of shipyard facilities and naval vessels. ${ }^{37}$ In March 1917 , the Secretary of the Navy created the Department of the Navy Compensation Board composed of naval officers experienced in engineering, management and accounting with "sufficient rank and experience to command the respect of the senior officials of contractors" and made the Board "responsible only to the Secretary of the Navy and entirely independent of any contract authorizing or disbursing agency. ${ }^{38}$

Like the War Department Board of Contract Adjustment, the Navy Compensation Board was composed of men with the prestige and experience to command the confidence and respect of contractors and was made completely independent of the organization engaged in the making and administration of contracts, so as to be in a position to render independent and impartial decisions. Unlike the War Department Board, it was in theory and in practice a board of experts who were supposed to draw on their own knowledge and experience in deciding questions without being restricted to the evidence in a "record." It is interesting that the Secretary of War who established the Board of Contract Adjustment as a quasi-judicial tribunal to hear cases and decide them on the record in the manner of a court was Newton D. Baker, an eminent lawyer, while the Secretary of Navy who established the Compensation Board as a board of technical experts was Josephus Daniels, not a lawyer.

Although the War Department board was washed away in the wholesale abolition of war agencies in the "return to normalcy" after the war, the Navy Compensation Board continued to function after the war and remained in existence until I944, when it was superseded by the Navy Department Board of Contract Appeals. ${ }^{39}$ The War Department did not have any formal contract procedure after the dissolution of the Claims Board in I922. ${ }^{40}$

\section{Origin of the Standard Fact-Disputes Clause}

The salient features of the standard government-wide disputes clause are: that it covers disputes as to questions of fact arising under the contract, which are to be decided by the contracting officer; that the decision of the contracting officer is final as to both parties, unless the contractor appeals within thirty days to the head of

${ }^{30}$ Report for Under Secretary of War dated May 28, I942, by committee of officers (Smith Committee) appointed to make study and recommendation on handling claims, quoting from "Notes as to the Compensation Board" by Dr. Henry W. Sweeney, Chief Accountant and Auditor, Navy Compensation Board.

${ }^{37}$ Ibid.

${ }^{38}$ Ibid.

${ }^{30}$ Directive, Secretary of Navy, December I, 1944, subj.; Determination of Disputes under Navy Contracts; Change in Name of Compensation Board to Navy Board of Contract Appeals.

${ }^{10}$ Smith, supra note I. 
the department, only the contractor having a right of appeal; and that, if the contractor appeals, the decision of the head of the department or his representative is final and conclusive on both parties. The first government-wide disputes clause was drafted by the Interdepartmental Board of Contracts and Adjustments and put into effect in 1926; and as issued in 1926, it had these salient features.

The Interdepartmental Board composed of representatives of the various government departments and agencies interested in government contracts was created by the first Director of the Bureau of the Budget (General Dawes) on November 22, I921, for the purpose of standardizing government contract forms, with instructions to draft simple, concise contract forms that were fair to both the government and the contractor. The proceedings of this Board from its creation until its dissolution in 1933 fill eight large volumes. ${ }^{41}$ The standard disputes clause was first promulgated as article fifteen of Standard Form 23 (construction contract).

In drafting the standard construction contract form, the disputes clause posed more of a problem and consumed more time of the Interdepartmental Board than any other provision. The Board spent hundreds of hours considering it, and there were numerous drafts, legal memoranda, subcommittee reports, and presentations from industry before the final draft was approved at the 248th meeting of the Board on August 3I, Ig26.

One of the most persistent complaints by contractors was delay in receiving payments due under government contracts; and there was general recognition of the need for a procedure under which prompt decisions could be made at the contracting officer level with sufficient finality to support payments and prevent the work from being delayed. At a joint construction conference held in I923, participated in by the Associated General Contractors of America, the American Institute of Architects, and the Federal Associated Engineering Societies, it had been agreed that the architect-engineer should make final decisions on all disputes, including interpretation of contract documents, except those affecting time and price; and taking a cue from such action as to private construction, the Board tentatively approved an all-disputes clause under which the contracting officer was to decide finally all disputes, except for a right to appeal within twenty days on items affecting time or price.

As to the appeal from the contracting officer's decision, serious consideration was given to commercial type arbitration, but legal and practical objections were raised. In addition to the need for authorizing legislation was the objection that it would deprive the department head of the control he needed to discharge his statutory responsibilities. Serious consideration was then given to a central board of contract appeals, but this encountered much the same objections as arbitration. It was recognized that contractors generally objected to an appeal being decided finally

11 The author examined the unpublished proceedings of the Interdepartmental Board of Contracts and Adjustments in the library of the Office of the Judge Advocate General, Department of the Army. Some information about the Board is presented in Harwood-Nebel Construction Co. v. United States, I05 Ct. Cl. I16, I28-56 (I946). 
by the department head. Many proposals were considered, including the following: final decision on appeal by department head; decision of appeal by department head with right of contractor to court review by giving notice of intent to do so within a limited time; department head decision with no finality; final decision by department head after advisory decision by an independent board.

To place the matter in proper perspective, it should be recalled that at the time of the Interdepartmental Board the dollar volume of government contracting was perhaps one per cent of what it is during the $x 960$ 's and that government contracting did not make nearly so large an impact on the nation's economy as it does now. Another significant factor was the role of the Comptroller General and the General Accounting Office (GAO), as the practice was for GAO to make a post-audit of each and every payment voucher and, whenever there was doubt as to the propriety of a payment, for the voucher, to be referred to GAO for direct settlement or advance approval. Initially GAO was not represented on the Interdepartmental Board; but a GAO representative was added prior to 1926 , and he began to exercise an important influence in the drafting of standard contract forms.

Until the r6gth meeting of the Board on January 15 , I925, all drafts of the disputes clause had made the clause applicable to "all claims, doubts and disputes," following the language of the War Department Adjustment of Claims and Disputes clause issued on September 7, I9r8. In an effort to meet GAO objections, the Board at its I6gth meeting modified the proposed clause by deleting "claims" and "doubts," so that the clause applied to "all disputes," and by adding a proviso making the decision of the department head subject to GAO review "upon matters involving legal construction." This modification was made in order to avoid possible encroachment on the Comptroller General, although the Board remained of the opinion that without the modification the clause would have been sustained by the courts so as to make decisions thereunder final absent fraud or gross mistake equating to fraud. However, GAO objected to the decision of a department head being final on anything except a question of fact and objected to legislation giving a department head the authority to make a decision having finality on anything except a question of fact. Finally at the meeting of the Board held on August 3I, I926 the proposed clause was modified so as to limit its scope to "all disputes concerning questions of fact arising under this contract."

When the standard disputes clause was adopted in 1926, the Interdepartmental Board recognized that it was not satisfactory to contractors in providing for a department head decision having finality without any provision for consideration by an independent impartial board. The Board still had this problem under consideration when the Board was dissolved in 1933, but there was no significant change in the standard disputes clause prior to World War II.

\section{E. World War II Boards of Contract Appeals}

When the Honorable Robert P. Patterson, a former U.S. circuit court of appeals judge, was serving as Under Secretary of War during the national defense build-up 
preceding this country's entry into World War II, he became seriously concerned with the inadequacies of the department's contract appeals procedure, which are illustrated by Penker Construction Co. v. United States. ${ }^{42}$ When the Court of Claims rendered its decision in this case on February 2, 1942, the problem was already under very active study within the department; and the court's decision was given consideration in the ultimate solution to the problem.

In Penker the contractor was refused permission to see the report on his claim that had been submitted by the constructing quartermaster, on the stated ground that it might be useful to him in prosecuting his claim against the government; and he was also told that no investigation would be made of the facts reported by the constructing quartermaster and that any doubts concerning interpretation of the specifications would be resolved in favor of the government. After congressional intervention, the Assistant Secretary of War told the contractor that he did not have time to hear appeals. The Assistant Secretary of War referred the appeal to a colonel, who referred it to a major, who referred it to a captain, who referred it back to the Quartermaster General, who referred it to the contracting officer, a brigadier general in his office, who referred it back to the captain who had prepared the contracting officer's decision from which the appeal had been taken. The Assistant Secretary of War's decision denying the appeal stated that he acted only in an administrative capacity, relying solely on the evidence and data presented to his office by the Office of the Quartermaster General. Under these facts, the Court of Claims held that the contractor had not received the kind of decision he was entitled to under the disputes clause and refused to accord any finality to such decision.

The first corrective action taken by the War Department as to contract appeals was on November 7 , I94I when contract settlement boards were established in the offices of the chiefs of the supply services (Quartermaster General, Chief of Engineers, Chief of Ordnance, and so on) to handle appeals up to $\$ 50,000$, and a board of contract appeals and adjustments was established in the Office of the Under Secretary of War to decide appeals in excess of $\$ 50,000^{43}$-each board to act under a statement of policy "to do complete and fair justice to the legitimate claims and contentions of every contractor." These boards were composed only in part of lawyers, and the members served on the boards in addition to their other duties. ${ }^{44}$ It is the author's opinion, based on his experience serving on the Contract Settlement Board in the Office of the Quartermaster General, that the press of other duties on wartime procurement work prevented board members from giving contract appeals the time and attention they deserved. While the boards did not have uniform procedures, generally they decided appeals on the basis of the administrative

$1296 \mathrm{Ct}$. Cl. I (I942).

${ }^{43}$ W.D. P \& C Gen. Dir. 72, Nov. 7, x94I (directing establishment of contract settlement boards in the supply services) and OUSW Office Memo. PC-L 334, Nov. 7, 1941. W.D. Memo. for Chiefs of Services, PC-L 167, Jan. 6, x942. See Smith supra note I.

14 Supra note 36 . 
record, except that when the contractor asked for a hearing there was a brief oral hearing without a reporter.

While these informal appeal boards were a great improvement over the situation illustrated by Penker, it was recognized that they fell short of a procedure that had the full confidence of industry. The problem was discussed from time to time at the weekly legal conferences held at Headquarters, Services of Supply (later called "Army Services Forces"), which the author attended.

Serious consideration was given to the substitution of a commercial type arbitration clause for the standard disputes clause. Bills to make the U.S. Arbitration Act applicable to government contracts were introduced in the Seventy-seventh Congress in 1942. ${ }^{45}$ When the views of the National Association of Manufacturers were solicited, it submitted a tentative report dated May 9 , I942 ${ }^{46}$ recommending revision of the disputes clause to limit finality of department head decisions to appeals involving not more than $\$ 15,000$, with a provision as to disputes in excess of $\$ 15,000$ giving the contractor the option either to appeal to the department head or to submit the dispute to a board of arbitration, and it made an alternate recommendation that the decision of the department head or his representative on an appeal be only "prima facie evidence of the disputed facts in any court of the United States." At a Headquarters, Services of Supply legal conference the author was asked to make a study of whether the legal objections to arbitration could be overcome without legislation; but shortly thereafter it was announced that Under Secretary Patterson's discussions with industry groups had convinced him that contractors had no real objection to the "arbitrators" being selected by the Secretary and Under Secretary of War, as long as they were guaranteed an opportunity for a hearing to present evidence and argument to the persons who were actually going to make the decision.

The Under Secretary of War appointed a committee of officers headed by Colonel Hugh C. Smith, JAGC, to make a study and recommendations for a complete system for handling claims. ${ }^{47}$ On May 28, I942 the committee submitted a comprehensive report (forty-seven pages of text plus exhibits) ${ }^{48}$ making recommendations for a contract appeals procedure. This committee was composed exclusively of judge advocate and finance officers, which is explained by the fact that the primary assignment of the committee was to make recommendations for a complete system for handling claims consisting principally of the tort and statutory claims processed by the Judge Advocate General's Office and the claims processed by the Finance Department. At that time neither the Office of the Judge Advocate General nor the Office of the Chief of Finance had any part in contract appeals. Neither Headquarters, Services of Supply nor any of the supply services were

${ }^{45}$ S. 2350 and H.R. 7r63, 77th Cong., 2d Sess. (I942). See Graske, Settlement of Government War Contract Disputtes, 29 A.B.A.J. I3 (1943).

${ }^{10}$ Supra note 36, Exh. 4 .

${ }^{47}$ Ibid.

${ }^{4}$ Ibid. 
represented on the committee, by reason of the purpose for which it was originally appointed. The composition of the committee no doubt explains the rather antisupply service slant of its report; and this, together with the fact that the supply services were swamped with wartime procurement, perhaps suggests why the supply services were not assigned any role in the trial of appeals before the Board created pursuant to the committee's recommendation.

Colonel Smith, the chairman of the committee, had served as a member of the World War I Board of Contract Adjustment, and his committee, after obtaining the comments and recommendations of other former members of that Board, recommended the creation of a board of contract appeals modeled closely after the World War I Board.

At the time there was agitation in Congress and within certain industry advisory groups for a government-wide contract claims board. Vigorously disagreeing with the idea of a government-wide board, the report stated:

It is deemed to be in the best interests of the Government, as well as of contractors, that contract disputes be adjusted within the War Department. However, unless the present system is revised so as to insure more general satisfaction, it is feared that strong effort will be made by contractors and their trade associations to have the Congress provide for a contract adjustment agency wholly independent of the War Department.

It is the view of the Committee that adjustments within the War Department may be made with less expense to the Government and the contractors and brought about more expeditiously than by an agency outside of the Department, and that the system herein proposed will operate satisfactorily to all concerned.

With the concurrence of Headquarters, Services of Supply, the committee strongly recommended that the deciding of appeals be completely removed from the supply services and made independent of the agencies engaged in negotiating and administering contracts by being placed in the Office of the Under Secretary of War, with appeals decided by a board whose members were selected by the Secretary and Under Secretary. The committee also recommended the elimination of intermediate appeals to the chief of a supply service. In support of its recommendation, the committee expressed the opinion that dissatisfaction with appeals being decided under existing delegations of authority was likely to arise, because (I) final appellate authority should be further removed from the negotiating agencies, (2) decisions were being made without giving the appellant an opportunity to be heard, (3) personnel charged with the duty of considering appeals were unable to give full, adequate and careful consideration to appeals, because of urgent requirements on their time made by procurement activities (a fact fully confirmed by the author's own experience), and (4) there was a feeling of discrimination against small claims.

In view of the then recently decided Penker Construction Co. v. United States, ${ }^{10}$ the committee was of the opinion that "the only safe course to pursue in order

t9 Supra note 42. 
to insure the finality of decisions" was to set appeals for hearings and "give the contractor an opportunity to present any pertinent evidence or argument he may desire to present."

Under Secretary Patterson concurred in the recommendations of the Smith committee, except for three changes which he made: (I) Instead of requiring that members of the appeal board be officers of the army, he left the qualifications of members open so that civilian members could be appointed. (2) Instead of having the board make recommended decisions to the Under Secretary with the final decision being that of the Under Secretary, he decided that the Board itself should render the final decision. (3) He provided for the Board to operate by divisions in rendering decisions. ${ }^{50}$

On August 8, I942 the Secretary of War issued a directive ${ }^{51}$ stating that "there is hereby constituted in the Office of the Under Secretary of War a board to be known as the "War Department Board of Contract Appeals." "52 The charter from the Secretary creating the Board designated it as "the duly authorized representative of the Secretary of War to hear, consider and decide as fully and finally as the Secretary of War might do, appeals to the Secretary of War under contracts" containing a provision for such appeals. The Board's charter, which was patterned closely after the World War I Board of Contract Adjustment, gave the Board "all powers necessary and incident to the proper performance of its duties," including the adoption, with the approval of the Under Secretary of War, of "its own methods of procedure and rules and regulations for its conduct and for the preparation and prosecution of appeals." The charter directed that parties, or their representatives, be given an opportunity for a hearing and to introduce evidence and granted authorization for any member or examiner of the Board to hold hearings, examine witnesses, receive evidence, and report the evidence to the Board or appropriate division thereof. There was no further definition of the Board's jurisdiction, and no limitation whatsoever was placed on the Board's authority to hear, consider, and decide appeals as fully and finally as the Secretary might do.

The Board's charter provided for appointments to the Board to be made by the Secretary upon the recommendation of the Under Secretary. The president and the recorder of the Board were required to be "persons trained in the law." In practice only lawyers were ever appointed to the Board; and Colonel Hugh C. Smith was appointed the first president of the Board on August 20, I942.53 The Board started

\footnotetext{
${ }^{\text {co }}$ Remarks of Colonel Hugh C. Smith, President of the War Department Board of Contract Appeals, before the Hqrs., ASF legal conference on Sept. 4, r942.

${ }^{61}$ Memorandum for Secretary of War dated Aug. 8, I943 signed by Robert P. Patterson, Under Secretary of War.

${ }^{63}$ Memorandum for the Under Secretary of War dated Aug. 8, I942 signed by Henry L. Stimson, Secretary of War. Information about WDBCA, including its charter and its rules as approved by the Under Secretary of War on Sept. 25, 1942, is published in 7 Fed. Reg. Ior88 et seq. (I942), codified as to C.F.R., ch. VIII, $\$ 8 x .3$ I8d (I942), and also published as paragraph 3I8D of the War Dep't Procurement Regulations.

${ }^{23}$ Memorandum for Secretary of War dated Aug. 20, I942 signed by Under Secretary of War, with appointment signed by Secretary of War.
} 
with three members, but with the increase in its workload this number was increased to seven members in May 1943, and in September 1944 increased to nine members.

At the time the War Department Board of Contract Appeals (WDBCA) was established, the department promulgated a new disputes clause which was made mandatory for all War Department contracts. ${ }^{54}$ The new clause was a modification of the previous standard fact-disputes clause then included in U.S. Standard Form 32 (supply contract) and U.S. Standard Form 23 (construction contract). The Smith committee had considered the substitution of an all-disputes finality clause, in connection with which it noted the decision of the Court of Claims in Silas Mason Co.v. United States, ${ }^{55}$ upholding the validity of a type of all-disputes finality clause, and also the decision of the Court of Claims in Callahan Walker Construction Co.v. United States, ${ }^{56}$ holding a question of amount of equitable adjustment in price under the changes clause to be a question of law not cognizable under the standard disputes clause. The committee noted particularly Judge Madden's dissent in Callahan Walker and that the Department of Justice had petitioned for certiorari. (Subsequently, the Supreme Court reversed the Court of Claims in Callahan Walker, ${ }^{57}$ upholding Judge Madden's 1942 view.) Its recommendation to adhere to the fact-disputes type of finality clause was influenced by an opinion of the Judge Advocate General to the effect that a disputes clause could lawfully cover questions of fact and questions of contract interpretation and law incidental thereto, but that decisions on questions of law not incidental to a dispute of fact could not be authorized by contract. ${ }^{58}$ (Subsequently the Supreme Court held to the contrary. ${ }^{59}$ )

The new disputes clause promulgated to implement the board of contract appeals procedure made the following significant changes in the standard fact-disputes clause: Express provision was made for appeals to the Secretary to be decided by a board as the Secretary's representative. A sentence was added stating: "The Contractor shall be afforded an opportunity to be heard and offer evidence in support of his appeal." Since the new clause was made mandatory, the effect of its publication was to prohibit intermediate appeals to the chief of a supply service.

Consistent with the requirements of the new War Department disputes clause, the WDBCA adopted rules granting the appellant a right to a hearing and providing for a full and complete transcript of the hearing as a part of the record. Other significant features of the new appellate system were that members of the Board were assigned on a full time basis to work exclusively on appeals; that the Board was placed outside the department's procurement organization directly under the

\footnotetext{
${ }^{54}$ By memorandum dated Aug. 13,1942 the Under Secretary of War directed the mandatory use of the new disputes clause, and it was promulgated by paragraph 318 of the War Dep't Procurement Regulations. The Under Secretary's memorandum also directed amendment of the disputes clause in previously executed contracts.

${ }^{55} 90$ Ct. Cl. 266 (1940).

${ }^{50} 95$ Ct. Cl. $3 I_{4}$ (I942).

${ }^{87}$ United States v. Callahan Walker Construction Co., 317 U.S. 56 (I942).

s8 Supra note 50.

${ }^{68}$ United States v. Moorman, 338 U.S. 457 (1950).
} 
Under Secretary of War; that members of the Board were appointed by the Secretary of War upon the recommendation of the Under Secretary; that the Board acted independently in deciding cases, as the Secretary and Under Secretary exercised no control over how any specific appeal was decided; and that the Board, composed of persons trained in law, functioned as a quasi-judicial tribunal in deciding cases on the basis of a record available to both parties where the contractor was on notice of what evidence would be before the Board for consideration and had an opportunity for confrontation and rebuttal.

The WDBCA was an immediate success in providing a tribunal for the speedy and inexpensive decision of appeals that gained the confidence of contractors as being fair and impartial. In the first year of its operations it docketed $4 \mathrm{r}_{3}$ appeals and rendered decisions in 244 cases. $^{80}$ The Under Secretary of War's annual report for the year ending June 30, I943 made the following comment based on the first year's operations of the Board: ${ }^{61}$

The work of the Board has aided greatly in the settlement of disputes and in reducing the volume of future litigation. The impartial attitude of its members also aids in the relations between the War Department and its contractors, who feel that the appeal procedure provides them with a fair day in court.

The Board's charter placed no limitation whatsoever on the Board's authority to act on an appeal as fully and finally as might the Secretary, nor did it otherwise define the Board's jurisdiction. However, the Board, in passing on its jurisdiction, took a more limited view than was intended or desired by the Secretary. It hesitated to decide questions of law that needed to be decided for the proper disposition of the appeal, and in some instances it referred questions of law to the Judge Advocate General for an opinion. ${ }^{62}$ Some color of sanction for such a procedure was to be found in the Board's charter, which, consistent with what had been done during World War I, contained a provision authorizing the Judge Advocate General, when deemed necessary by the Under Secretary of War and upon his request, to assign a judge advocate as general counsel to the Board. In Fred A. M. deGroot, Inc., ${ }^{63}$ for example, the Board dismissed an appeal involving a claim for performing extra work, on the ground that deciding the appeal required making a decision on the interpretation of the specifications, which was a question of law beyond the jurisdiction of the Board. Appeals involving claims under the changes clause were dismissed, because the contracting officer had not waived the ten-day notice provision. ${ }^{64}$ As a result of this development, the Secretary of War issued his famous July 4, I944 memorandum, instructing the Board in disposing of appeals to exercise such delegable authority as the Secretary himself might exercise through contract or

${ }^{\circ 0}$ Smith, supra note $\mathrm{x}$, at 82 .

ox Ibid.

${ }^{62}$ Tuller Painting Corp., WDBCA No. 30, Feb. I6, I944, I CCF 45; W. F. Trimble \& Sons Co., WDBCA No. 27, Feb. 18, I944, I CCF 47.

${ }^{\circ}$ WDBCA No. 108, June 8, 1943, I CCF 148.

ot Kirk Building Co., WDBCA No. I, March 6, I943, I CCF 67. 
otherwise, ratify or waive acts of subordinates where the Secretary himself could do so "as deemed necessary and desirable to arrive at a just and equitable adjustment and disposition of the dispute involved in the appeal," and pass on timely appeals not coming strictly within the disputes clause. ${ }^{65}$

On August I4, I944 the Acting Secretary of the Navy appointed new members (lawyers) to the Navy Compensation Board and authorized it to act as the agent of the Secretary of the Navy to hear appeals under Navy contracts and submit findings and recommendations to the Secretary with respect thereto. On December I, I944 the name of this Board was changed to the "Navy Department Board of Contract Appeals." On June 2r, r945, by order signed by H. Struve Hensel, Acting Secretary of the Navy, the Navy Department Board of Contract Appeals was designated to "act as the agent and authorized representative of the Secretary of the Navy in hearing and considering" appeals under Navy contracts and to "decide the issue as fully and finally as the Secretary of the Navy might do." Thus did the Navy change from the "board of experts" concept to the "quasi-judicial tribunal" concept of a board to decide contract appeals. Like the War Department, the Navy gave its Board of Contract Appeals the broad authority to hear and decide appeals as fully and finally as the Secretary might do, and the procedures and rules of the Navy Board of Contract Appeals were patterned closely after WDBCA.

\section{F. Establishment of the Armed Services Board of Contract Appeals}

When the National Security Act of $1947^{67}$ abolished the War Department and created the Department of the Army and the Department of the Air Force, the name of WDBCA was changed to Army Board of Contract Appeals, ${ }^{68}$ without any change in its membership, and it decided appeals under both Army and Air Force contracts. The ASBCA created effective May I, I 949 by joint directive of the secretaries of the Army, Navy and Air Force was composed initially of the nine members of the Army Board of Contract Appeals and the three members of the Navy Board of Contract Appeals and it took over the appeals pending before the two boards. ${ }^{60}$ The new Board, created as a merger of the Army and Navy boards, was divided into Army, Navy, and Air Force panels, each panel to decide appeals under contracts of its department.

The joint directive chartering ASBCA stated that ASBCA "is hereby designated and shall act as the authorized representative of the respective Secretaries of the Army, Navy and Air Force in hearing, considering and determining as fully and finally as might each of the Secretaries" appeals under contract disputes clauses. However, the new charter contained two sentences on jurisdiction of the Board

\footnotetext{
${ }^{05}$ Io C.F.R. $\$ 803.318 \mathrm{~d}-7$, as amended in 1945 Supp.

${ }^{68}$ Navy Procurement Directives, Chapter V Disputes, Part iii Navy Board of Contract Appeals, II $\mathrm{I}, 66 \mathrm{I}(\mathrm{x} \mathrm{I}-\mathrm{I} 6-45)$.

${ }^{67} 6 \mathrm{I}$ Stat. 495, approved July 26, I947 (codified in scattered sections of 5, 10, and 50 U.S.C.).

${ }^{68}$ Rostrell M. Austin (Ed.), Digest of the Decisions of the Army Bonrd of Contract Appeals, 1942-50.

${ }^{\mathrm{BO}} \mathrm{Id}$. $1950-53$.
} 
that were not in the charter of the predecessor boards. The first such sentence stated that, when the appeal was under a fact-disputes clause, the Board might "decide all questions of law necessary for the complete adjudication of the issue." This was in accordance with how the predecessor boards had interpreted their jurisdiction.

The other sentence affecting the Board's jurisdiction was as follows:

Unless the contract provides otherwise, when in the consideration of an appeal it appears that a claim for unliquidated damages is involved therein, the Board shall, insofar as the evidence permits, make findings of fact with respect to such claims without expressing opinion on questions of liability.

Although no such provision had been in the charters of the predecessor boards, the Secretary of War's July 4, I944 memorandum ${ }^{70}$ had instructed the board to:

c. Find and administratively determine the facts out of which a claim by a contractor arises for damages against the Government for breach of contract, without expressing opinion on the question of the Government's liability for damages.

The ASBCA charter "unliquidated damages" provision was actually a modification of the language of the July 4, I944 memorandum "breach of contract" provision. Since Colonel Hugh C. Smith, the president of WDBCA, drafted the July 4, I944 memorandum, the explanation for the provision may be found in the article that he wrote about WDBCA in 1943 , wherein he said: ${ }^{71}$

It has been held time and time again (Cramp \& Sons v. United States, 216 U.S. 494; Brannen v. United States, 20 Ct. Cls. 219) that in the absence of an authorizing statute, the Secretary of War is without authority to adjust and settle claims against the United States for unliquidated damages; and the Board has followed these decisions.

\section{G. Improvements in ASBCA Procedures}

The Supreme Court decisions in United States $v$. Moorman ${ }^{72}$ and United States v. Wunderlich ${ }^{73}$ in 1950 and I95I served to impress on the Department of Defense and ASBCA the importance of preserving intact the "administrative record" upon which the Board based its decision. Prior thereto there had been full recognition of the importance of the Board's decision being based on an integrated administrative record available to both parties for examination; but after the conclusion of an appeal the Board had followed the practice of returning to the contracting agency documents in the appeal record that had been submitted to the Board by such agency. After these two Supreme Court decisions the Board adopted the practice of preserving the appeal record intact so that it would be available for examination in the event of any future litigation involving the subject matter of the appeal.

\footnotetext{
${ }^{70}$ 10 C.F.R. $\S 803.3$ I8d (Supp. 1945).

${ }^{71}$ Smith, stipra note $\mathrm{I}$, at 85 .

73 Supra note 59 .

${ }^{73} 342$ U.S. 98 (I95I).
} 
Prior to I955 the rules of ASBCA and its predecessor boards had not provided for the filing of any pleadings. By way of background, the World War I Board of Contract Adjustment had had assigned to it, and made a part of its staff, judge advocates who prepared the cases for hearings, tried the cases before the Board, and otherwise assisted the Board in the discharge of its duties. In keeping with the World War I practice, the charter of WDBCA had provided that, upon request of the Under Secretary of War, the Judge Advocate General might assign judge advocates as trial attorneys or examiners. WDBCA followed the practice of having the trial attorney assigned by the Judge Advocate General examine the appeal file and prepare the case for presentation to the Board. Frequently the Board member assigned to hear the appeal did not examine the appeal file before the hearing and depended on the government trial attorney to make an opening statement at the hearing outlining the facts and explaining the issues of the appeal. Though the trial attorney represented the government, he was expected to act dispassionately and assist the Board in "getting the true facts," which is the purpose of a hearing.

There began to be complaints from attorneys representing appellants at hearings that, as a result of the issues not being clearly defined, the testimony would wander at great length and occasionally the issues would not be clarified by the end of the hearing. ${ }^{74}$ In March 1954, representatives of the Army, Navy, and Air Force panels held a meeting with representatives of the American Bar Association, the Bar Association of the District of Columbia, and the Hoover Commission to discuss revision of the Board's rules. ${ }^{75}$ Through their joint efforts an extensive revision of the rules was made. The new revised rules, ${ }^{76}$ approved on June 30 , r955, reflected for the first time the concept of the substantial evidence rule made applicable to contract appeals by the newly enacted Wunderlich Act. ${ }^{77}$ The new rules, modeled after the Federal Rules of Civil Procedure, were based on the concept of simple, concise, and direct pleadings, consisting of the appellant's complaint and the government's answer, coupled with pre-trial conferences and discovery to narrow issues and stipulate facts not in dispute, thereby to shorten hearings and speed up the disposition of appeals.

The new rules served to shorten hearings in various ways. Not only were the issues better defined by pleadings, but the pre-hearing procedures served to cause the hearing member to become familiar with the case in advance of the hearing and to dispose of many matters that might otherwise consume a great deal of time at the hearing, such as production and examination of documents, arranging for the appearance of necessary witnesses, depositions from witnesses who could not be present at the hearing, and stipulations as to facts not in dispute.

In $195^{8}$ the operations of ASBCA became a matter of concern to Congress. On April $15,195^{8}$ the House Appropriations Committee issued a staff report in which

\footnotetext{
7t Hearings, supra note 4 , at 823 .

${ }^{75} I d$. at $819-20,823-24$.

${ }^{76}$ ASPR App. A, Part 2, as amended by Change No. 8, Aug. 23, 1955, 32 C.F.R. $\$ 30.1$ (1961).

${ }^{77}$ Act of May II, I954, 68 Stat. 8I, 4I U.S.C. $\$ 32$ I-322 (1958).
} 
it stated that "the period of time required for processing an appeal through the Board was becoming so lengthy as to rather seriously impair the effectiveness of the procedure." 78 Due to a combination of circumstances, the backlog of appeals pending before the Board had built up so large as to raise a question of whether the Board was providing more speedy relief than was available through the judicial process, which was one of the major reasons for the Board's existence. The Subcommittee for Special Investigations of the House Armed Services Committee (commonly known as the Hebert Committee) inquired into the administration and operations of ASBCA, in connection with which it obtained data on the cost of the Board's operations in relation to its accomplishments and as to whether the Board was necessary. ${ }^{78}$

Starting in 1957 the assistant secretaries for procurement of the three military departments became concerned with the backlog and inaugurated an intensive and continuing program to ascertain the causes of delay and institute necessary remedial action. It was found that there had been a large increase in the workload of the Navy and Air Force panels, which was taken care of by adding more members to these panels, thereby increasing the membership of the Board to twenty-one members. Due to a sudden influx of appeals growing out of an investigation of military clothing contracts, the backlog of appeals pending before the Army panel rose to 594 as of September I, I957, and trial examiners were assigned to the Army panel temporarily to assist it in eliminating the "hump."

The chairmen of the three panels were given necessary administrative powers to improve the efficiency of the Board's operations. A monthly analysis was made of "year old cases" to ascertain and eliminate impediments to their disposition. The assistant secretaries found some causes of delay that were beyond the control of the Board, but that could be corrected through actions by the government trial attorneys and the contracting agencies, such as compliance with the Board's rules with respect to time of submission of the documents to be included in the appeal file (known as the Rule Six papers) and the filing of the government's answer. Also it was found that action on many appeals had to be suspended by the secretary because of investigations by the Department of Justice and that in many cases the Board had suspended action on appeals at the request of the appellant to allow time for settlement negotiations. The Board took vigorous action to require both the government and appellants to meet time requirements on filing of pleadings and briefs and to discourage time-consuming motions tending to delay final disposition of appeals. The time interval between docketing and decision was also reduced by setting appeals for hearing promptly after they were ready, refusing continuances except for good cause shown, and requiring simultaneous briefs.

At the time the Hebert Committee held its last hearing about ASBCA on December $4,195^{8}$, the backlog of the Army panel had been reduced from a high of

${ }^{78}$ Hearings, stpra note 4, App. II.

${ }^{70}$ Ibid. 
594 to $374 .^{80}$ The committee hearing showed that significant progress had been made by all three panels of the Board in reducing the number of pending appeals and in reducing the average time and mean time for disposing of appeals. This reduction continued into ${ }^{2} 6{ }_{3} 3$ before there was a leveling off of the number of pending appeals and processing time. The normal processing time for an appeal involving pleadings, hearing, and briefs was found to be eight and one-half months; hence, the normal work in process of pending appeals was deemed to be the number of appeals docketed per month times eight and one-half months, to which must be added the "cats-and-dogs" tied up by extended unavoidable delays.

In recent years contractor complaints of delay in receiving ASBCA decisions have been rare indeed. The Board has a policy of advancing cases for good cause shown, such as financial hardship.

Other actions were taken during the Hebert Committee inquiry to improve the efficiency of the Board's operations. An optional accelerated procedure for appeals involving less than $\$ 5,000$ was put into effect, thereby reducing the time and expense of processing small claims. ${ }^{81}$ With the increase in the size of the Board to twenty-one members, it was deemed impractical and inefficient to have "full Board decisions," and there was substituted a procedure whereby the three panel chairmen decided the appeal whenever the division to which the appeal was assigned was unable to submit a decision which the three panel chairmen would "waive."

At the same time the Assistant Secretary of the Army for Logistics took actions ${ }^{83}$ that had the effect of assuring a closer working relation between the Army trial attorneys and the technical services from which the appeals originated. The technical services were given increased rights to be consulted and participate in the preparation and trial of appeals and to have their views presented to the Board, although the trial attorney responsibilities remained in the Office of The Judge Advocate General. The role of the Army trial attorney became less that of an assistant to the Board and more that of counsel to the technical service in presenting the government's side of the case.

The Hebert Committee inquiry disclosed that the operations of the ASBCA for fiscal years 1957 and 1958 had cost $\$ 769,408$, during which time the board disposed of $\mathrm{r}, 42 \mathrm{r}$ appeals involving claims aggregating $\$ 26,670,984$ - of this amount $\$ 6,386,443$ was allowed; claims totaling $\$ 7,519,804$ were sustained as to entitlement and remanded for determination of the amount, and $\$ 12,764,736$ was denied. $^{84}$

The opinions of the secretaries of the military departments as to the necessity, efficiency, and effectiveness of ASBCA are shown in the following excerpts from their answers to questions asked by the Hebert Committee:

By the Department of the Army:

${ }^{80} \mathrm{Id}$. at 798 .

${ }^{81}$ Dec. 3I, 1958 revision of Rules of ASBCA, ASPR App. A, Part 2, as amended by Change No. 44, Feb. 27, 1959 .

${ }_{82}$ Ibid.

${ }^{88}$ Hearings, supra note 4 at 800-02.

84 Id. at 788. 
It is my considered opinion that the Armed Services Board of Contract Appeals occupies an essential place in effective Department of the Army procurement and contracting. Similar boards have, for the same reason, been established in other agencies of the Government. I believe the Board does serve the public interest and does discharge the Army's contractual responsibilities. It would be impossible for the Secretary to review personally these disputes and decide them. The disputes clause which provides for appeals also requires the contractor to proceed with performance pending resolution of the dispute, thus providing for continuing supply of military equipment.

We believe that the rules of the Board effectively carry out two basic requirements: that of providing for expeditious resolution of disputes, and, at the same time, providing both parties to the disagreement with adequate opportunity for presentation of their evidence and positions....

The rules of the Board were modeled after the Court [sic] of Federal Procedure and to the degree feasible parallel those of the Court of Claims. However, it is believed that any move to modify the rules to more nearly approach those of the Court of Claims would result in more formal procedures, with resulting delays in the disposition of disputes. The Board is an administrative body and its rules of procedure, since the thorough revision in I955, are best calculated to serve the purpose for which the Board was established; i.e., among other things, to provide for settlement of disputes at the lowest possible cost to the appellant and the Government. . . .

.. . The appeal procedure is designed to settle those contractual disagreements which cannot be resolved directly between the contractor and the contracting officer. It furnishes contractors a forum for settlement of factual issues both more cheaply and more expeditiously than recourse to the courts. The fact that few cases ultimately go to the courts seems to demonstrate the effectiveness of the procedure. ${ }^{85}$

\section{By the Department of the Navy:}

... the Board is now providing fair, impartial and expeditious determinations of disputes with contractors which are not settled at the contracting officer level. Also, experience has demonstrated that the need of an appeal procedure is clear. For one thing, the number of cases decided by the Board but which never reach the Court of Claims reflects the usefulness to contractors of maintaining this tribunal. In addition, I am informed that the Board has a good reputation with contractors and with the bar. Finally, it is the fact that contractors can complete a case more expeditiously before the Board than in the Court of Claims or other tribunals. ${ }^{86}$

The Department of the Air Force gave in substance the same answers to the questionnaire as did the Army and Navy and made the following additional points:

Speed in handling contract claims is only one facet of the problem, and overemphasis on speed can only result in either depriving the parties of their full opportunity to be heard or in hasty judgment. Both are bad. ...

Comparative studies of the time taken by the Air Force panel of the Armed Services Board of Contract Appeals and the time taken by the Court of Claims to reach decision after docketing indicates a mean time for the Air Force panel of 12 months and for the Court of Claims 35 months. ...87

\footnotetext{
${ }^{85} 1 d$. at $85 \mathrm{x}-52$.

${ }^{88} \mathrm{Id}$. at $854-55$.

${ }^{87} \mathrm{Id}$. at 858 .
} 


\section{H. Reconstitution of ASBCA as a Unitary Board}

A reorganization within the military establishment resulted in the establishment of the Defense Supply Agency with a large procurement mission outside the three military departments. Defense Supply Agency contracts provided for appeals under the disputes clause to the Secretary of Defense or his authorized representative, and it was necessary to arrange for handling appeals under Defense Supply Agency contracts.

In the meantime the government-wide problems relating to contract appeal boards had been under study by the Administrative Conference of the United States (first convened by President Eisenhower in 1953 and continued by President Kennedy on April 30, I96I) composed of government officials, practicing lawyers, and legal scholars. After eighteen months of study, the Administrative Conference submitted to the Senate Committee on the Judiciary a "final report" which included the following recommendation applicable to ASBCA:

\section{ARMED SERVICES BOARD OF CONTRACT APPEALS}

Since 1949 the Armed Services Board of Contract Appeals has consisted of three semiautonomous panels (Army, Navy, and Air Force), each with its own chairman, determining appeals from disputes arising under contracts of its particular service. Recently, with the establishment of the Defense Supply Agency, the addition of a fourth panel has been under consideration.

In order to permit better utilization of board members through greater flexibility in the assignment of cases, to avoid situations wherein one panel is heavily overloaded while another is current, and to reduce the expense of maintaining three or four separate file systems, separate dockets, and separate clerical staffs, the Conference recommended (Recommendation No. 6) that the Armed Services Board of Contract Appeals be constituted as a unitary board in the Defense Establishment. For like reasons the recommendation urged that subsidiary boards such as the Corps of Engineers Board and the Quartermaster's Board, to the extent practicable, be eliminated as soon as possible. ${ }^{88}$

At that time the Army Engineers had a Corps of Engineers Board of Contract Appeals (first established in 1946) which acted as the authorized representative of the Chief of Engineers in deciding appeals under a form of disputes clause providing for appeal from the contracting officer's decision to the Chief of Engineers or his authorized representative. Under the forms of construction contracts used by the Corps of Engineers, the decision of the Engineer Board, as the designated representative of the Chief of Engineers for deciding appeals, was final on civil works contracts, but on military construction contracts the Engineer Board was only an intermediate board of contract appeals, and the contractor was given a right of further appeal to the Secretary of the Army or his authorized representative-that is, to ASBCA-if he was dissatisfied with the decision of the Engineer Board. It had long been generally recognized that the time and expense of two administrative

${ }^{88}$ Administrative Conference of the United States, Selected Reports of the Administrative Conference of the United States Submitted by the Chairman of the Subcomm. on Administrative Practice and Procedure to the Senate Comm. on the Judiciary, S. Doc. No. 24, 88th Cong., Ist Sess. 8-9 (1963). 
appeals was not justified, but there had been disagreement over whether the solution should be to make the decision of the Engineer Board final or to provide for appealing direct from the contracting officer's decision to ASBCA. The recommendation of the Administrative Conference served to resolve this issue in favor of providing for direct appeal to ASBCA. As anticipated by the Administrative Conference, the elimination of intermediate appeals on Army military construction contracts accomplished a reduction in the administrative expense of appeals.

By joint directive of the Secretary of Defense and the secretaries of the three military departments dated March 20, r962, ASBCA was reconstituted as a unitary board and designated as the authorized representative of the Secretary of Defense and the secretaries of the three military departments in hearing, considering and determining contract appeals as fully and finally as might each of the secretaries. ${ }^{89}$ The only significant change in the definition of the Board's authority from that contained in the 1949 charter was that the "unliquidated damages" sentence was eliminated and the following was substituted:

When in the consideration of an appeal it appears that a claim is involved which is not cognizable under the terms of the contract, the Board may, insofar as the evidence permits, make findings of fact with respect to such a claim without expressing an opinion on the question of liability.

Under the revised charter the three panels attached administratively to each of the three military departments were abolished, and the Board was reconstituted as a unitary board to operate under general policies established or approved by the Assistant Secretary of Defense (installations and logistics). All members of the Board are appointed jointly by the four assistant secretaries for procurement. The unitary board has a chairman and two vice chairmen; and the chairman has authority for the internal organization and administration of the Board. The chairman has organized the Board into divisions consisting of the chairman or a vice chairman and two other members. The decision on an appeal by the majority of the members of a division constitutes the decision of the Board when the chairman and the two vice chairmen signify their approval of such decision; but, if a majority of the members of a division are unable to agree on a decision, or if the chairman or one of the vice chairmen does not signify approval of the decision, determination of the appeal is made by the chairman and vice chairmen.

The four assistant secretaries for procurement approved new rules for the unitary ASBCA effective August $I, 1963^{\circ 0}$ The new rules make few changes of substance in the 1955 rules, the principal changes being designed to reduce the time from docketing to hearing of an appeal by shortening the time allowed for filing the government's answer, authorizing the Board to waive any pleadings deemed unnecessary to define the issues, and requiring the filing at an earlier date of the documents formerly filed by the government trial attorney pursuant to Rule Six.

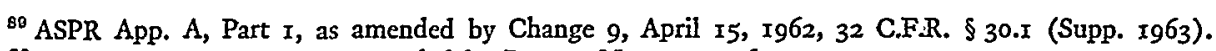

${ }^{\circ}$ ASPR App. A, Part 2, as amended by Rev. 3, Nov. 15, 1963. 


\section{IV}

\section{Actions Under the Disputes Clause Preceding the Appeat}

The procedure under the standard disputes clause has three separate and distinct but over-lapping phases. The first, and perhaps most important, phase is the effort of the contracting officer and the contractor to dispose of the matter by mutual agreement, which fortunately in most instances is successful. The disputes clause refers to disputes "which are not disposed of by agreement"; and it is contemplated that the parties attempt to dispose of the dispute by agreement before there is any resort to unilateral decision under the disputes clause. Settlement by agreement is inherently more satisfactory when a fair and equitable settlement can be made. Failure to try to settle a dispute by agreement before the contracting officer renders a decision under the disputes clause can subject both the government and the contractor to the expense of an unnecessary appeal.

The first phase includes also the various preliminary actions and directions of the contracting officer preceding any agreement or unilateral decision. For example, when a question arises during performance as to the intended meaning of specifications or as to a conflict in specifications or a deficiency that needs correction, it is the duty of the contracting officer to instruct the contractor as to how the government desires the contractor to proceed with performance. Concerning this aspect of the disputes procedure, the Supreme Court said that the disputes clause "creates a mechanism whereby adjustments can be made and errors corrected on an administrative level, thereby permitting the government to mitigate or avoid large damage claims that might otherwise be created."

When efforts to dispose of the dispute by agreement prove unsuccessful, this brings the parties to the second phase of the disputes procedure, which is the final decision of the contracting officer under the disputes clause. Such decision, when rendered in accordance with the requirements of the disputes clause and implementing government regulations, becomes "final and conclusive" on both the government and the contractor, unless the contractor appeals. The government has no right to appeal, but the contractor can prevent any finality of the contracting officer's decision by giving a simple notice of appeal within thirty days after he receives it. If the contractor does not give a timely notice of appeal, the decision of the contracting officer becomes final, and both parties acquire vested rights under such decision.

In view of the serious consequences that may flow from the contracting officer's decision, whether or not appealed, the contracting officer should not render a final decision under the disputes clause until he and his staff have made sufficient investigation to ascertain the relevant facts, as failure to know the facts may lead to the making of an erroneous decision. Sufficient investigation for the making of a correct decision is proper-first, as a matter of fairness to the contractor; second, in the interest of good business relationships with contractors; and, third, to protect the interests of the government. There have been many instances where contracting

${ }^{91}$ United States v. Joseph A. Holpuch Co., 328 U.S. 234, 239 (1946). 
officers have rendered decisions terminating contracts for default, only to have the default termination converted by ASBCA on appeal to a termination for the convenience of the government, with the result that the contractor is relieved from payment of the government's claim for excess costs of repurchase and in addition is able to collect a large convenience termination claim from the government, all because the contracting officer terminated the contract for default when the contractor's delay in deliveries was due to excusable causes. If a contracting officer makes sufficient investigation to ascertain that the contractor's delay is excusable before he terminates for default, he will in most cases refrain from terminating the contract and thereby save the government from having to pay a convenience termination claim.

There are obvious advantages to both the contractor and the government for a dispute to be handled in its initial stages at the operating level; and experience demonstrates that most disputes can be so disposed of by give-and-take negotiations. There is no cutoff between the first phase negotiations for agreement and the second phase unilateral decision by the contracting officer. In fact, the opportunity for settlement by agreement continues to exist during the third phase appeal up to the time the dispute is finally decided by the board of contract appeals; and in many instances settlements are negotiated after an appeal is filed and sometimes after the hearing. Not infrequently the hearing brings out facts previously unknown to one or both of the parties which produce a settlement.

Contracting officers vary greatly in ability, experience, and fair-mindedness, as will always be so when the human element is present; and there is variation in the size and competence of the staffs of specialists available to them for advice and assistance. There can be no sharp line between what the contracting officer does as the official responsible for protecting the interests of the government and what he does when wearing the hat of impartial decider of the dispute. In either case he should be fair. In the initial stage of the dispute when he is making his investigation and having his negotiations with the contractor, he is not likely to know whether the steps being taken will lead to a mutual agreement or a unilateral decision. Whether the dispute is disposed of at the local level by agreement or by a decision of the contracting officer that is acceptable to the contractor and does not result in an appeal depends much on the skill and fairness of the contracting officer and how thoroughly and carefully he does his job. However, it would be a serious mistake to regard an appeal as reflecting adversely on the contracting officer. It is the author's opinion, based on his experience at the operating level, that there is as much danger of the contracting officer's failing to protect the interests of the government by making an agreement or rendering a decision that is too favorable to the contractor as there is of his being unfair to the contractor.

It it essential to efficient, economical, and expeditious contract administration that the disputes procedure include the pre-appeal aspects under which the contracting officer is authorized to act on disputes at the operating level without sub- 
mission to higher authority. The man on the spot with a background of first-hand knowledge not reflected in any records has an inherent advantage over anyone at a higher level. Furthermore, there is an imperative need for authority to make prompt decision at the contracting officer level, so as to keep the contractor at work and prevent costly delays. It is necessary that the agreements and decisions at the contracting officer level have sufficient finality to support payments, because if they were subjected to being "second-guessed" by higher authority or the GAO, payment would be delayed until an authoritative decision could be made; and the ability of contractors to obtain financing and performance bonds would be jeopardized. ${ }^{22}$

Authority to make decisions necessarily entails power to make mistakes. Experience shows only too well that contracting officers sometimes do make mistakes, that they are not always fair, that emotions and personalities at the operating level sometimes color thinking, and that sometimes the only way to get a fair and impartial decision is for the dispute to be considered by people who have not become emotionally involved in the dispute. Furthermore, contracting officers are not expected to have the know-how or facilities for adducing the pertinent evidence and making findings and conclusions in complex dispute situations. As a safeguard to the contractor, it is only fair that he should have a right of appeal if he feels aggrieved by the contracting officer's decision. The existence of a right of appeal under procedures that provide a speedy and inexpensive decision of the appeal has a salutary effect in facilitating settlements at the contracting officer level and preventing arbitrary decisions by contracting officers. It would be manifestly unfair and unreasonable to deny the contractor a right of appeal and expect him to be bound irrevocably by the decision of one so directly involved in the controversy as the contracting officer, particularly when the contracting officer is not expected to base his decision on a record available to the contractor for examination. No one advocates such a procedure.

\section{$\mathrm{V}$}

\section{ASBCA as the Secretary's Authorized Representative}

As previously mentioned, the authority of the head of an executive department to appoint a board of contract appeals comes from his general statutory authority to administer his department; and the authority of ASBCA comes from the charter it has received from the four secretaries and is derivative from their authority. Since the Board's authority comes from the secretary, the extent of its authority depends on the secretary's authority. The secretary's authority to render a decision having any binding effect on the contractor is purely contractual. A decision on an appeal by the secretary or his authorized representative is "final and conclusive" on the contractor only because, and to the extent that, the contractor has contractually consented to such finality by entering into the contract containing the disputes clause.

${ }^{22}$ Hearings Before a Subcommittee of the House Committee on the Judiciary on H.R. I8 39 and S. 24, H.R. 3634, and H.R. 6946, Reviezy of Finality Clauses in Government Contracts, 83d Cong., Ist \& $2 \mathrm{~d}$ Sess. ser. No. 12 (July I953-January 1954) [hereinafter cited as House Hearings]. 
Another important point to bear in mind is that, while the Board has been authorized to hear, consider, and decide the appeal as fully and finally as the secretary of the department concerned might do, it is not the authorized representative of the secretary of the department concerned for all purposes, but only for the limited purpose of hearing, considering, and deciding timely appeals under the disputes clause.

The following dictum by Judge Madden is often quoted as describing the role of the Board in deciding appeals:

It is evident that the Secretary was authorizing the Board to act for him in the way that any owner would act if a contractor was dissatisfied with the way he was treated by the owner's representative in charge. He would listen to the contractor's story, and if he thought that his representative had been unfair, he would reverse him. He would do this, not because the contract gave him any authority to make a final decision which would bar the contractor from relief in the courts for breach of contract, but because it would be the natural and fair way for an owner to act. ...93

Judge Madden was talking about action taken by the Board under authority of the Secretary of War's memorandum of July 4, I944. When applied to the deciding of appeals under the disputes clause, the dictum involves a fundamental misconception of the Board as the secretary's representative.

We shall not quibble with the technicality that the secretary is not the owner, but only an official of the owner-namely, the United States of America-just as Judge Madden was an official of the United States of America, appointed and confirmed in the same way, and drawing his salary from the same source, as the secretary of an executive department. We agree that the head of a department has a responsibility, non-judicial in character, for representing and protecting the proprietary interests of the government with respect to contracts of his department and that his duty to protect such interests does not require him to be impartial in the sense that a judge is expected to be impartial. We agree further that the dictum is a correct statement of what an ethical owner acting in his enlightened self-interest would be expected to do. All these things the secretary could do and would be expected to do without any disputes clause in the contract or any other contract provision conferring on him the right to decide disputes.

The secretary of a military department has a staff of thousands to represent and assist him in discharging his responsibilities for protecting the interests of the government. This staff acts for him on numerous matters of contract administration that do not come under the jurisdiction of ASBCA. After an appeal is filed, ASBCA can decide the appeal; but it has not been authorized to negotiate a settlement agreement with the contractor, although the secretary can and has delegated authority to negotiate settlements to persons other than ASBCA. When a contractor is in default, the government has an election either to terminate the contract for default or to continue the contract in effect and require the contractor to

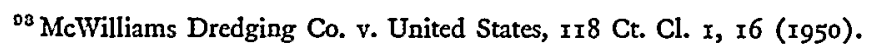


perform. The secretary can decide whether or not the government's discretionary right to terminate for default should be exercised; but on appeals from default terminations ASBCA has held that it has no authority to decide whether the discretionary right to terminate should be exercised and can only decide whether the government had a right to terminate for default under the facts and applicable law..$^{04}$ An owner can grant a contractor a no-consideration price increase whenever he deems it to his advantage to do so-for example, to keep the contractor in business as a needed source of supply-and the secretary of a military department can grant extraordinary relief to a contractor whenever he determines such to be in the interest of national defense; but he has not delegated such authority to ASBCA. When there is no timely appeal from a contracting officer's decision, the secretary can reverse the contracting officer's decision, if he decides that under the facts found by the contracting officer his decision is wrong as a matter of law; but ASBCA has no authority to act in the absence of a timely appeal..$^{95}$

When the head of a department decides an appeal under the disputes clause, he is acting in an entirely different capacity from that of an owner doing what it would be natural for an owner to do under the circumstances. The owner in representing his interest as owner is motivated by self-interest and business ethics without being under any duty to be impartial in his dealings with the contractor. In contrast, when the department head decides an appeal under the disputes clause, he acts in the capacity of the official designated by the contract to decide the dispute; and, when so acting, he acts for both the contractor and the owner and is under a legal duty to be impartial in rendering a fair decision that will be final and conclusive on both of the parties. ASBCA represents the secretary only when he is wearing the hat of impartial arbiter designated by the contract to decide the dispute. In no sense is the Board the agent of the government as a party to the contract. Speaking through Mr. Justice Holmes, the Supreme Court decided the capacity of a department head in deciding a dispute under a finality clause when it said "the Secretary of the Navy is to be regarded as a third party and stranger to the contract rather than as representing the United States." ${ }^{\prime \prime}$ In deciding an appeal under the disputes clause ASBCA is, both in legal theory and in fact, the representative of the secretary of the department concerned only in the secretary's capacity as the impartial third party designated in the contract to act on behalf of both the contractor and the government, closely analogous to what a court or a board of arbitration would do.

Another important point is that the secretary's authority in his capacity as a department head with statutory powers is utilized in hearing, considering, and deciding appeals: first, by the secretary directly in establishing the Board, selecting and appointing members, financing its operations, providing it with necessary support services (office and hearing facilities, stenographic, clerical, reporting, and

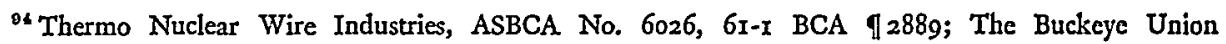
Casualty Co., ASBCA No. 6770, 6I-2 BCA I 3215.

${ }^{95}$ Keenan Pipe \& Supply Co., ASBCA No. 7873, I962 BCA \3319.

${ }^{\circ 6}$ United States v. McMullen, 222 U.S. 460,470 (I9I2). 
so on) and monitoring its activities to the extent necessary to determine whether it is adequately staffed for the accomplishment of its mission; and secondly, by the secretary's delegation to the Board of certain of his authority as a department head so as to empower the Board to require the production of government records and the attendance of government officers and employees as witnesses. Through such use of the executive power the Board has been clothed with authority over its proceedings somewhat analogous to the powers of a court, although there are important differences.

ASBCA's service to the department (and to contractors) in the accomplishment of the procurement mission goes beyond the deciding of specific disputes. Its published decisions provide guidelines to government personnel engaged in contract administration and to contractors for the resolution or prevention of disputes under other contracts involving similar issues. When the Board decides disputes promptly after they arise, its decisions frequently disclose the need for action within the department in modifying specifications and contract provisions and correcting inspection and other administrative procedure, with the result that future misunderstandings, disputes, and claims can be avoided.

Frequently an appeal involves a claim where only one element is in dispute, such as whether the claim is barred by a release or the proper interpretation of the specifications. Since the Board represents a secretary who also exercises control over the contracting officer, the Board is able to decide only the issue in dispute and save the expense of hearing all issues necessary to a complete adjudication of the claim by remanding the appeal to the contracting officer for deciding the other elements of the claim and disposing of the appeal in accordance with the Board's decision.

\section{VI}

ASBCA Proceedings Are De Novo

Before the establishment of WDBCA to hear and decide appeals the appellate procedure under the disputes clause consisted generally of an administrative review at the department head level of an administrative report on the dispute submitted by the contracting officer and the chief of the supply service or bureau, which was in a very real sense an administrative review of the contracting officer's decision. In the early days of WDBCA there was some holdover of the concept of reviewing the contracting officer's decision; and statements may be found in early decisions indicating a presumption of the correctness of the contracting officer's decision and that the appellant had the burden of proving the contracting officer's decision to be wrong. ${ }^{97}$ However, the establishment of a procedure giving the parties a right to a hearing to present evidence and the requirement that the decision on appeal be based on an integrated record available to both parties for examination led as a

${ }^{07}$ Wind Turbine Co., ASBCA No. 2206, October 25, 1954; A. S. Jason, Army BCA No. 1848, February I7, I950; Stiers Bros. Construction Co., WDBCA No. 535, May 3r, 1944, 2 CCF 785; H. W. Zweig Mfg. Co., WDBCA No. 577, June r5, I944, 2 CCF 88r. 
natural consequence to the rule that the Board's decision must be based on a de novo proceeding. The present rule followed by ASBCA is that once an appeal has been filed this deprives the contracting officer's decision of all finality and that on appeal there is no more presumption that the contracting officer is correct than there is a presumption that the contractor is correct as to the matter in dispute. 08

The contracting officer is not expected to hold a hearing before he renders his decision, nor is he expected to base his decision on, and have it substantially supported by, an integrated record; hence, generally there is no record supporting the contracting officer's decision which can be reviewed on appeal. Even where there is, under the disputes clause, as modified in 1942 , the contractor is entitled by his very contract to a hearing at which he may introduce evidence in support of his position. Obviously the Board could not ignore the evidence received at the hearing and deny an appeal solely on the basis that the contracting officer's decision met all the Wunderlich Act finality standards. Whether the contracting officer's decision meets the Wunderlich Act finality standards is totally irrelevant, as it loses all finality (except as a direction to the contractor on how to proceed) if a timely appeal is filed, but is final and conclusive despite failure to meet the Wunderlich Act tests if no timely appeal is filed.

An appeal from the contracting officer's decision is somewhat analogous to an appeal to a court of record from a judgment of a justice of the peace. A timely appeal must be filed to prevent the judgment of the justice of the peace from becoming final, but on appeal the court of record tries the case de novo, as there is no record which can be reviewed. Another analogy may be found in an appeal to the Tax Court from a unilateral determination of excessive profits by the Renegotiation Board..$^{99}$ Like a contracting officer, the Renegotiation Board obtains data from the contractor and enters into negotiations with a view to consummating renegotiation by agreement. It is only after the efforts to renegotiate by agreement fail that the same agency which conducts the negotiations makes a unilateral determination; and it is not expected to base its decision solely on an integrated record available to the contractor but may even use data pertaining to the contractor's industry obtained in business confidence from his competitors. Under such circumstances the Renegotiation Act gives the contractor a right to a trial de novo, if he chooses to go to the Tax Court.

In response to the questionnaire of the Hebert Committee, the Department of Defense stated that a de novo trial of an appeal was mandatory, unless the contractor waived a hearing and the appeal was submitted for decision on the record..$^{\mathbf{1 0 0}}$

As a corollary to the de novo trial rule, ASBCA and the secretaries it represents have a policy of assisting the parties by all available means in obtaining the attendance

\footnotetext{
${ }^{\text {as }}$ Eastern Tool \& Mfg. Co., ASBCA No. 4815, 58-2 BCA $q$ x947; Dawson Engineering Co., ASBCA No. 7762 , I963 BCA \3759, motion for reconsideration, I963 BCA 13804 .

${ }^{90}$ Renegotiation Act of I951, § I08, 50 U.S.C. App. \$1218 (r958). See Koehler, Renegotiation: Evidence and Burden of Proof, 45 VA. L. REv. I (1959).

${ }^{100}$ Hearings, supra note 4 , at $850-6 \mathrm{r}$.
} 
of witnesses and in adducing all pertinent evidence. While ASBCA has no subpoena power, the powers of the secretaries over their own personnel are exercised in requiring the attendance as witnesses of government officers and employees whenever the appellant requests their attendance and makes a showing of need for their testimony. When such persons are unable to attend a hearing by reason of being stationed overseas or for any other reason, the worldwide facilities of the Department of Defense are utilized in obtaining their depositions. The Department of Defense also assists the appellant to obtain the testimony of former government officers and employees whose testimony he desires by giving them assurance that it is Department of Defense policy that they testify freely and frankly as to matters within their knowledge, and in appropriate cases by issuing them invitational travel orders under which they attend the hearing at government expense. ASBCA follows the policy of requiring each party to produce documents and witnesses under its control and does not hesitate to draw unfavorable inferences against a party who fails without good cause to comply with such a demand.

\section{VII \\ Finality of Decisions Under the Disputes Clause}

\section{A. Finality Tests Other Than Wunderlich Standards}

From the time of Kihlberg in 1878 there has been a continuing struggle between the Court of Claims and the Supreme Court, during which time the Court of Claims has consistently sought to find ways to decide cases "correctly" according to the evidence before it without having its hands tied by decisions under contract finality clauses, while the Supreme Court has consistently given effect to decisions under finality clauses through the application of the same principles that apply to private contracts. In this struggle several well-established grounds for denying finality to decisions under finality clauses have been developed.

The first principle of finality under the standard disputes clause is that the decision must be that of the person designated by the disputes clause to make the decision. ${ }^{101}$ Since the sole basis for the decision being "final and conclusive" on the contractor is contractual, it is elementary that the contractor is not bound by a decision unless it is made by the person whose decision he has consented to accept. This means that the initial "final decision" preceding the appeal must be that of the "contracting officer" who by definition includes, in addition to the person executing the contract on behalf of the government, any other properly designated contracting officer and the authorized representative of a contracting officer acting within the limits of his authority. ${ }^{102}$ It means further that the decision on the appeal must be that of the secretary of the department concerned, which by

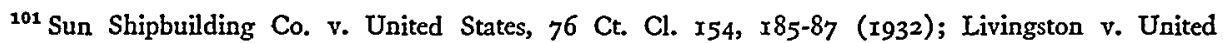
States, IoI Ct. Cl. 625,638 (I944); United States Casualty Co. v. United States, I07 Ct. Cl. 46, 68 (I946); Climatic Rainwear Co. v. United States, II5 Ct. Cl. 520, 564-66 (1950).

${ }^{102}$ Standard definitions clause, ASPR 7-I03.I, 32 C.F.R. \$ 7.103.I (Supp. 1963).
} 
definition includes the Under Secretary or any Assistant Secretary, or the Secretary's "duly authorized representative for the determination of such appeals." "103

As a corollary to the first principle, in order for the decision to have any finality, it must be made strictly in accordance with the procedural requirements of the disputes clause and implementing government regulations. ${ }^{104}$ Since failure to make a timely appeal will operate as a forfeiture against the contractor, both $\mathrm{ASBCA}^{105}$ and the Court of Claims have held that the contracting officer's decision is not final and conclusive so as to bar a subsequent appeal under the disputes clause or recovery in the Court of Claims unless there is strict compliance with the requirements of the disputes clause and with applicable government regulations in the rendition of the contracting officer's decision. This means, inter alia, that a contracting officer's unappealed decision will not be accorded any finality unless it is reduced to writing and signed by the contracting officer with a copy delivered to the contractor or sent to the contractor by registered or certified mail.

Furthermore, the decision must clearly inform the contractor that it is a final decision under the disputes clause and of the contractor's right of appeal and how to appeal. Regulations requiring that the contracting officer's decision clearly inform the contractor that it is the contracting officer's final decision on the-matter in dispute and will become final and conclusive on the parties if no appeal is filed within thirty days were first promulgated within the Department of Defense in 1952. ${ }^{106}$ Since then there has been an increasing emphasis on the importance of strict compliance before any finality can attach to the contracting officer's decision. With this development, complaints about the shortness of the thirty-day appeal period have practically disappeared.

It should be observed that a final decision under the disputes clause, either a decision on an appeal or an unappealed contracting officer's decision, is "final and conclusive" on both parties to the contract; and courts have not hesitated to accord finality to such a decision against the government as well as against the contractor. In numerous cases where the GAO has refused to accept decisions under contract finality clauses in favor of the contractor, the Supreme Court and the Court of Claims have refused to go into the merits of the claims and granted recovery to the contractor solely on the basis of the finality of the decision in the contractor's favor made under the disputes clause. ${ }^{107}$ Complaint is sometimes made that, since the contracting officer's unappealed decision is final and conclusive on both parties, the government as well as the contractor should have a right of appeal. Since space limitations do not permit discussion of the pros and cons of this question, it will be dismissed

${ }^{103}$ Ibid.

${ }^{104}$ Climatic Rainwear Co. v. United States, supra note Ior; Bostwick-Batterson Co. v. United States, I5I Ct. Cl. 560 (1960); Keystone Coat \& Apron Corp. v. United States, 150 Ct. Cl. 277 (1960).

${ }^{208}$ Wood of Texas Industries, ASBCA No. 5697, 59-2 BCA श 2464; Robinson \& Wilson, Inc., ASBCA No. 8493, 1963 BCA I 3867; Frank Gust Decorating Service, ASBCA No. 7198, 6I-2 BCA I 3200.

${ }_{100}$ ASPR 7-103.I2, 32 C.F.R. \$ 7.103-12 (196r); and ASPR I-3I4, 32 C.F.R. \$ Y.3I4 (Supp. 1963).

${ }^{102}$ United States v. Mason \& Hanger Co., 260 U.S. 323 (1922); Carroll v. United States, 76 Ct. Cl. ro3 (1932). 
with the observation that, aside from formidable administrative difficulties of giving the government a right of appeal, there is a general feeling among contractors that the contractor's unilateral right of appeal serves to "even up" a dispute procedure which would otherwise be unduly loaded in favor of the government.

Another principle of finality is that a decision under the disputes clause will not be accorded finality unless it is made on a matter that is cognizable under the disputes clause. This principle has two aspects. The first has to do with the scope of the disputes clause itself, which by its terms pertains only to "any dispute concerning a question of fact arising under this contract which is not disposed of by agreement." Since the contractor has not contracted to be bound by any decision except on a dispute coming within the scope of the disputes clause, a decision under the disputes clause has finality only to the extent that it is on a dispute coming within the purview of the disputes clause.

The second aspect of the principle that the matter decided must be cognizable under the disputes clause has to do with limits on the authority of the department concerned to settle and dispose of claims. When a contractor appeals from the denial of a claim involving a dispute concerning a question of fact arising under the contract not disposed of by agreement, so as to come literally within the terms of the disputes clause, it has been held that the appeal as to such claim cannot be decided under the disputes clause, and must be dismissed by ASBCA as beyond its jurisdiction, if the claim is for unliquidated damages for breach of contract, as distinguished from a claim "arising under the contract."108 The author's view that the executive departments have authority to settle by agreement with the contractor unliquidated claims for damages for breach of contract was developed in a law review article several years ago. ${ }^{109}$ As brought out above, the "unliquidated damages" and "breach of contract" limitations on jurisdiction were not in the charter of ASBCA's predecessor board, were originally promulgated in the Secretary of War's memorandum of July 4, I944 written by the predecessor board's first president, and were carried over into the original (r949) ASBCA charter, but were eliminated from the Ig62 revision of the ASBCA charter. The current charter substitutes as a jurisdictional test that the appeal involve a claim that is "cognizable under the terms of the contract." The rule that ASBCA and its predecessor boards were lacking in authority to decide appeals involving claims for breach of contract was based on the concept that, if a department was lacking in authority to settle a claim for breach of contract, it could not decide the merits of such a claim under the disputes clause. Such rule ignores the fact that the authority to decide under the disputes clause is purely contractual and is in no sense an exercise of the department's statutory authority to settle claims. In deciding appeals ASBCA does not exercise any statutory settlement authority of the executive departments but acts as that impartial

${ }^{108}$ Bonaco Construction Co., ASBCA No. 6627, 6r-I BCA I 2916; Donald M. Drake Co., ASBCA No. 4188, 57-2 BCA I I385; Amherst Steamship Corp., ASBCA No. 3474, 57-2 BCA II 1400.

${ }^{200}$ Shedd, Administrative Authority to Settle Claims for Breach of Government Contracts, 27 Geo. WASH. L. REv. 481 (1959). 
third party designated by the parties in the contract to act on behalf of both of them.

The rule, as generally understood, that the executive departments are without authority to settle claims for breach of contract, either by agreement with the contractor or by decision under the disputes clause, proved to have consequences that were unfortunate from the standpoint of both the government and the contractor, as it forced the parties to go to the courts and incur the delay and expense of litigation before claims for damages for breach of contract could be settled and paid, even though there was no real dispute as to liability or the amount of damages. To obviate this undesirable situation, government procurement agencies started several years ago adding various contract clauses designed to convert what would otherwise be claims for damages for breach of contract into claims payable under such contract clauses and, hence, to be regarded as "arising under the contract." 110 This trend has continued to the point where the field of claims for breach of contract that are not regarded as "arising under the contract" is becoming very narrow indeed. Also there has been an increasing tendency for contract appeal boards to give a broad interpretation to contract clauses as vehicles for the administrative settlement of meritorious contract claims. Decisions where ASBCA dismisses an appeal for lack of jurisdiction as involving a claim for breach of contract are becoming increasingly rare.

The first case where the Court of Claims ruled on the applicability of the disputes clause to a claim for damages for breach of contract was Phoenix Bridge Company v. United States, ${ }^{111}$ decided in 1937 , wherein the court held that the contractur might by-pass the disputes procedure and bring suit without first presenting his breach of contract claim to the contracting officer and obtaining a decision under the disputes clause. The Court of Claims has interpreted the disputes clause as not expressing an intention that the contracting officer should have the power to decide a question of breach of contract when the contracting officer has disclaimed any authority to do anything about the contractor's claim for breach of contract. The interpretation of the disputes clause was extended into a holding that it was not intended to authorize the making of findings of fact binding on the Court of Claims when the executive department had no authority to determine the question of liability, the court saying: "Ordinarily, when the facts are once found, the case has been nine-tenths decided."112 The interpretation of the disputes clause as not authorizing fact findings on breach of contract claims that are binding on the court has been applied by the Court of Claims both to unappealed decisions of contracting officers $^{113}$ and findings by the department head on appeal..$^{114}$

${ }^{110} \mathrm{Id}$. at 515 -1 6.

${ }^{111} 85$ Ct. Cl. 603, 629-30 (1937).

112 Langevin v. United States, xoo Ct. Cl. 15, 30 (1943).

${ }^{112}$ Railroad Waterproofing Corp. v. United States, 133 Ct. Cl. 9II (1956), a claim under the changed conditions clause which had been dismissed by the appeal board, because the appeal was untimely.

${ }_{124}$ Continental Illinois National Bank \& Trust Co. v. United States, 126 Ct. Cl. 63r, 640 (r953); Anthony P. Miller, Inc. v. United States, Ir I Ct. Cl. 252, $33^{\circ}$ (1948). 
The second decision of the Court of Claims in Volentine \& Littleton v. United State $^{115}$ displays a cavalier treatment of finality of administrative fact findings on the basis of so-called breach of contract. The case involved a contract for the clearance of a reservoir site above a dam being constructed. The government closed the dam and inundated the reservoir site before the contractor had completed the clearance work, as a result of which the contractor was delayed and subjected to increased costs of performance. The contractor asked for a time extension and remission of liquidated damages on the ground that its delay was excused by the government's action in closing the dam and also asked for a price increase on account of the extra work entailed by the government's premature closing of the dam. The contracting officer found that the contractor was entitled to a price increase of $\$ 6,054$ for the extra work required by the premature closing of the dam and was also entitled to a time extension of thirty-four days for the delay due to such cause. On appeal, the Corps of Engineers appeal board, after a hearing, reached the same conclusion as had the contracting officer. The Court of Claims held that the contractor was entitled to an additional price adjustment of $\$ 33,946$ and an additional time extension of forty-five days, resulting in an additional remission of liquidated damages of $\$ 2,250$.

The court's decision, written by Judge Madden, disposed of the question of finality of the Engineer Board decision on the ground that the government's action in closing the dam before the contractor had completed clearance of the dam site was a breach of contract entitling the contractor to damages concerning which "the contracting officer did not have authority to give relief, his decision and that of the reviewing board had no finality."116 (Note that Judge Madden refers to the Engineer Board as a "reviewing board" simply reviewing the decision of the contracting officer, although the Engineer Board decision was made in a de novo proceeding with a hearing.) The contracting officer had in fact granted the contractor relief, both in time and money, for the premature closing of the dam. The import of Judge Madden's opinion is that a contracting officer is powerless to grant a contractor the time extension provided for in the contract for an excusable cause of delay, if such excusable cause of delay constitutes a breach of contract by the government. The court did not hold that the time extension found by the Engineer Board was arbitrary or capricious or fraudulent or not supported by substantial evidence, although such issue was squarely raised by the pleadings. The court simply held that the administrative findings of fact as to the causes and extent of delay were not binding on the court because of the government's alleged breach of contract in closing the dam. Disregarding the question of whether the disputes clause authorizes administrative fact finding when there is no authority to grant administrative relief, the decision is clearly wrong in holding that there was no authority to grant administrative relief.

${ }^{116}$ I 44 Ct. Cl. 723 (1959).
${ }^{110}$ Id. at 726. 
The doctrine of breach of contract as a ground for denying finality to a decision under the disputes clause, first invoked by the Court of Claims in cases where the executive department had expressly disclaimed authority to grant the contractor any relief, has been extended by the Court of Claims repeatedly to cases where the executive department had asserted authority and in fact granted relief to the contractor and even to cases where the contract itself provides for the relief to be granted by the department for the very act found by the court to be a breach of contract. ${ }^{117}$

The whole concept of absence of authority in the executive departments to consider and make decisions on breach of contract claims has been under serious attack for the past ten years. ${ }^{118}$ In the author's opinion, when ASBCA renders a decision under its 1962 revised charter, breach of contract can no longer be relied on by the Court of Claims as a basis of denying finality to the Board's decision.

In view of the Supreme Court's decision in United States v. Joseph A. Holpuch Company, ${ }^{119}$ it seems certain that the Supreme Court will not uphold the Court of Claims rule that administrative fact findings are not binding on it in a breach of contract suit when a case is presented under a finality clause clearly expressing an intent that breach of contract claims be subject to such clause. Holpuch involved an all-disputes clause. The contractor failed to appeal from adverse decisions of the contracting officer and proceeded to bring suit in the Court of Claims. The Supreme Court held that the all-disputes clause applied in accordance with its terms literally to all disputes arising under the contract and that the contractor's claims were barred by the contracting officer's adverse decisions from which the contractor did not appeal.

\section{B. Questions of Law}

We take up now finality as applied to questions of law. So much has been written on the subject that we need not labor the difficulty-indeed the impossibility -of separating questions of fact from questions of law..$^{120}$ There is no difficulty in recognizing the distinction between law and fact; but generally they are so interrelated as to be incapable of separate determination as a practical matter. It is scarcely an over-statement to say that all monetary claims involve mixed questions of law and fact. In the interpretation of technical specifications, for example, they cannot ordinarily be interpreted correctly by a lawyer without the aid of evidence from technical experts and persons familiar with the usages of the industry; nor on the other hand can they be interpreted correctly by an engineer having all

${ }^{117}$ P. L. Saddler v. United States, 287 F.2d $4 \mathrm{II}$ (Ct. Cl. I96I); Bostwick-Batterson Co. v. Unitcd States, supra note I04, at 563; supra notes $\mathrm{II}_{3}$ and $\mathrm{II}_{5}$. But see the recent cases, W. H. Edwards Engineering Co. v. United States, Ct. Cl. No. 218-59 (April 5, 1963), and Cannon Construction Co. v. United States, 319 F.2d I73 (Ct. Cl. 1963), which may indicate a change in position of the Court of Claims as to administrative authority in "breach of contract" cases.

${ }^{218}$ Braucher, supra note $\mathrm{I}$, at 494; Crawford, stupra note $\mathrm{I}$; Crawford's disssenting opinions in Armond Cassil, Ine., ASBCA No. 438, June I6, I950, and Simmel-Industrie Meccaniche Societa per Azioni, ASBCA No. 6r4I, 6r-I BCA q $29 \times 7$.

119328 U.S. 234 (1946). (1959).

${ }^{120}$ See Birnbaum, Questions of Law and Fact and the Jurisdiction of ASBCA, I9 Fev. B.J. I20 
necessary technical knowledge but unfamiliar with the legal principles of contract interpretation.

From an early date the Court of Claims resisted attempts to make decisions under finality clauses binding on it as to questions of law. ${ }^{121}$ It was not until 1950 that the issue was squarely decided by the Supreme Court in United States v. Moorman.122 The Court of Claims had held ${ }^{123}$ that the contracting officer's decision on interpretation of specifications under an all-disputes clause was not conclusive on the court, as interpretation of specifications was not a question of fact. The Supreme Court reversed the Court of Claims without deciding whether or not interpretation of specifications was a question of fact, holding that the all-disputes clause was final and conclusive in accordance with its terms without regard to whether the dispute was on a question of fact or a question of law.

At the time of the Supreme Court's decision in Moorman, it was the policy of the government, as expressed in procurement regulations, to use the standard factdisputes clause rather than an all-disputes clause. In fact, one of the grounds relied on by the Court of Claims for holding the all-disputes clause to be invalid in providing for finality as to administrative findings on questions of law was that use of the all-disputes clause was unauthorized and in conflict with the standard clause prescribed for use by government regulations. Nevertheless, non-standard all-disputes clauses were appearing in some government contracts and had been held to be valid by the Supreme Court. Moorman excited a storm of protest from contractors and members of the bar, as well as the GAO, and the government procurement agencies imposed no objection to legislation prohibiting the use of a contract clause making the decision of any administrative official final on a question of law, which was enacted as section two of the Wunderlich Act. ${ }^{124}$

Section two of the Wunderlich Act did not prohibit the use of an all-disputes clause; it merely prohibited finality from attaching to a decision on a question of law made under a disputes clause. In revising the standard disputes clause to conform to the requirements of the Wunderlich Act, no change was made in the scope of the clause limiting it to "any dispute concerning a question of fact arising under this contract," but a paragraph (b) was added expressly providing that, in deciding a dispute coming within the scope of paragraph (a) of the clause, any question of law arising in connection therewith might also be decided without any finality attaching to the decision on a question of law. Under the present disputes clause, a decision on a dispute coming within the scope of such clause is "final and conclusive" on both parties to the contract, to the extent provided by the clause and permitted by the Wunderlich Act, as to questions of fact, but has no finality as to any question of law. A distinction is made between jurisdiction and

${ }^{121}$ Lyons v. United States, $30 \mathrm{Ct}$. Cl. 352, 365 (I895); Collins and Farwell v. United States, 34 Ct. Cl. 294, 332 (I899).

${ }^{132}$ Supra note 59.

${ }^{123}$ Moorman v. United States, Ir3 Ct. Cl. 159 (1949).

134 68 Stat. 8x, 4 I U.S.C. $\$ 32 I-322$ (I958). 
finality. Under the disputes clause, the contracting officer, and on appeal the department head or his authorized representative, have jurisdiction and authority to decide all questions of fact and law necessary for a complete adjudication of the matter in dispute, but finality attaches only to the determination of the facts. This is how the disputes clause was interpreted by ASBCA before the addition of paragraph (b).

\section{Fraud and Its Equivalent}

From the beginning it has been recognized that no finality will be accorded to a decision under a finality clause, if the decision is tainted with fraud or bad faith. However, a subjective intent to defraud is difficult to prove by direct evidence, and proof of intent to defraud is ordinarily established by inferences drawn from conduct, as a person is presumed to intend the natural and probable consequences of his acts. Thus a decision may be so grossly erroneous as to give rise to the inference that the person making the decision intended to defraud the aggrieved party. ${ }^{125}$

The reluctance of the Court of Claims to make findings of fraud or bad faith on the part of public officials, coupled with the insistence by the Supreme Court that full effect be given to decisions under finality clauses in the absence of a finding of fraud or bad faith, is illustrated by the Ripley case which three times went to the Supreme Court before a judgment in the contractor's favor was upheld. ${ }^{128}$ The case involved a contract for the construction of a jetty which prohibited the contractor from laying crest blocks until the government agent in charge determined that the mound had consolidated. The contractor asked permisssion to lay crest blocks in December when the mound had in fact consolidated, but the government engineer in charge refused to allow the contractor to start laying crest blocks until the following May, as a result of which the cost of performance was increased greatly. The Court of Claims dismissed the contractor's petition, because the contractor had not charged "fraud or gross error," but later entered a judgment for the contractor in the amount of $\$ 14,73^{2} .05$. The Supreme Court remanded the case to the Court of Claims with instructions to make additional findings and remanded it a second time to make "a direct and unequivocal finding as to the good or bad faith of the inspector."

The Court of Claims then found that the engineer's refusal to permit laying of crest blocks "was gross error and an act of bad faith on his part." Thereupon the Supreme Court affirmed the judgment in favor of the contractor.

Thereafter the Court of Claims liberally applied the doctrine of bad faith implied from gross mistake. A foreshadowing of the Court of Claims decision in Wunderlich came with its decision in Bein v. United States, ${ }^{127}$ decided in 1943, when the Court of Claims, speaking through Chief Judge Jones, held that "decisions of the contracting

${ }^{25}$ I2 AM. Jur. Fraud and Deceit $\$$ IIg (r938).

${ }^{128}$ Ripley v. United States, 43 Ct. Cl. 490 (1908), 45 Ct. Cl. 62I (1910), 46 Ct. Cl. 68I (IgII); 47 Ct. Cl. 647 (I9I2); 220 U.S. 49 I (I9II); 222 U.S. I 44 (IgIr); 223 U.S. 695 (I9I2).

${ }^{127}$ IOI Ct. Cl. I44 (1943). 
officer and the head of the department on appeal on both issues were so grossly erroneous that they should be set aside as amounting to bad faith." ${ }^{288}$ In a separate concurring opinion, Judge Madden said that public officials who become heads of departments and contracting officers are rarely guilty of conduct which merits such strong condemnatory language as "arbitrary," "capricious," and "so grossly erroneous as to imply bad faith" and expressed the view that the court should be able to set aside administrative decisions shown by the evidence to be wrong without being forced to apply epithets to public officials. ${ }^{129}$ In a 1945 decision the Court of Claims refused to accord finality to a department head's decision on an appeal, stating in an opinion written by Judge Madden: $:^{130}$

We see no point in applying such words as "arbitrary," "capricious" or "bad faith," which obviously are inapplicable, in order to reach the result which justice demands. We think that unawareness of the problem on the part of the deciding officer is an equally good reason why his decision should lack finality.

Wunderlich v. United States, ${ }^{131}$ decided by the Court of Claims in 1950 , involved a Bureau of Reclamation contract for the construction of a dam, where the contractor submitted thirty-two claims aggregating $\$ 463,547-47$ and appealed from the contracting officer's decision denying twenty-one of the claims. The Secretary of the Interior affirmed the contracting officer's decision, and the contractor brought suit. All the claims except No. I 7 involved contract interpretation.

In a decision written by Judge Madden, the court referred to the Supreme Court decision in Moorman and said that it still adhered to its position that interpretation of specifications was a question of law not made final by the standard factdisputes clause, ${ }^{132}$ citing as authority certain decisions of WDBCA rendered before the Secretary of War's July 4, I944 memorandum. ${ }^{133}$ He erroneously stated that ASBCA sometimes, in its discretion, dismissed without deciding appeals involving interpretation of contract specifications, citing in support of such statement five decisions by the Navy Panel of ASBCA dismissing appeals on the ground that they involved claims for breach of contract. ${ }^{134}$

The Court of Claims allowed recovery of $\$ 172,203.23$ in addition to what had been allowed by the contracting officer. Of this sum $\$ 555,748.44$ was for Claim No. I7, which was asserted under an extras clause providing for computation of the price adjustment on the basis of costs; and the sole issue as to Claim No. I7 was the contractor's cost incurred in performing the extra work. In refusing to be bound by the cost determination made by the contracting officer and affirmed on appeal by the department head, the court said that the administrative treatment of the claim had been "arbitrary and capricious" in that it was made in disregard of the

${ }^{138} I d$. at 165 .

${ }^{130} \mathrm{Id}$. at $\mathrm{x} 67-70$.

${ }^{130}$ Henry Ericsson Co. v. United States, I04 Ct. Cl. 397, 429 (I945).

${ }^{132}$ II7 Ct. Cl. 92 (1950).

${ }^{133}$ Id. at 212-13.

${ }^{193} I d$. at 214 . See supra notes 62 and 63 .

136 Id. at $2 \times 5$. 
known practices of the trade, proper accounting methods, and known facts as to actual costs. ${ }^{135}$ However, Judge Madden did not apply the epithet of "so grossly erroneous as to imply bad faith," repeatedly used by the court in previous cases under circumstances providing less justification.

The Supreme Court granted certiorari as to Claim No. I7 and in United States v. Wunderlich ${ }^{136}$ decided in I95 $^{\mathrm{I}}$ reversed the Court of Claims as to such claim. It said that in Ripley gross mistake implying bad faith had been equated to fraud, but that the Supreme Court had consistently upheld the finality of department head decisions under finality clauses, unless fraud had been alleged and proved, while in this case fraud had been neither alleged, proved, nor found. Then it said that findings that the department head was "arbitrary," "capricious," or "grossly erroneous" were not the equivalent of fraud and that "fraud" meant "conscious wrongdoing, an intention to cheat or be dishonest."137

\section{Wunderlich Legislation}

The Supreme Court's decision in Wunderlich, closely following Moorman, precipitated howls of protest from industry and the bar, which led to several bills being introduced into Congress to overcome the effects of these two decisions. The Senate and House Judiciary Committees held extensive hearings ${ }^{\mathbf{1 8 8}}$ where they inquired into the broad question of the need for and scope of finality clauses and the extent of finality that should be permitted, receiving testimony from industry groups, members of the bar, legal scholars, and witnesses from various interested government agencies. After the hearings started, but before any permanent legislation was enacted, the Department of Defense modified the standard disputes clause so as to provide for no finality of a decision on an appeal if "determined by a court of competent jurisdiction to have been fraudulent, arbitrary, capricious, or so grossly erroneous as necessarily to imply bad faith."130

The Associated General Contractors of America recommended legislation with retroactive effect prohibiting the inclusion in a government contract of any clause giving any degree of finality to any decision of a contracting officer, department head, or other government official on any question of law or fact. The Association reviewed its consistent efforts to eliminate finality clauses from government contracts continuously from the time it made its first recommendation to the Interdepartmental Board in I922, pointing out that it had no objection to contracting officers making decisions on questions of law and fact as necessary to keep the job going, and that it favored "administrative review" of such decisions, but that it had consistently opposed any limitation whatsoever on judicial review of administrative rulings. ${ }^{140}$

${ }^{135} I d$. at 219 .

${ }^{186} 342$ U.S. 98 (r95I).

${ }^{137} \mathrm{Id}$. at 100 .

${ }^{138}$ Hearings Before a Subcommittee of the Senate Judiciary Committee on S. 2487, Finality Clauses in Government Contracts, 82d Cong., 2d Sess. (1952) [hereinafter cited as Senate Hearings]; House Hearings, supra note 92.

${ }_{130}$ ASPR 7-I03.12 as amended by Change No. 4, Sept. 15, I952, 32 C.F.R. \$7.103-12 (196r).

${ }^{240}$ Senate Hearings, supra note 138 , at $21-32$, and House Hearings, supra note 92, at $6 \mathrm{x}-75$. 
Other industry spokesmen and most members of the bar did not take such an extreme position as did the Associated General Contractors. Generally they did not oppose finality clauses, but favored legislation which would restore the law to what they conceived it to be prior to the Supreme Court decisions in Wunderlich and Moorman-that is, that a court could deny finality to a decision under a finality clause, not only for fraud in the sense of conscious wrongdoing, but also when it found the decision to be arbitrary, capricious or so grossly erroneous as to imply bad faith, and that a court would not accord finality to an administrative decision on a question of law. There was also strong sentiment for adding the substantial evidence rule of the Administrative Procedure $\mathrm{Act}^{140 \mathrm{a}}$ as another basis for denying finality.

The Comptroller General objected to Wunderlich and Moorman, because of the degree of finality sanctioned by the Supreme Court, which in his opinion would prevent the GAO from disallowing claims based on illegal and improper decisions in favor of the contractor, unless it could prove conscious wrongdoing. He asked that the proposed legislation be modified to authorize the GAO to deny finality on the same basis as a court of competent jurisdiction. The initial reaction of proponents of remedial legislation was to welcome the support of the Comptroller General; but soon there began to appear expressions of fear that inclusion of the GAO in the legislation on the same basis as the courts would so impair the finality of contracting officers' decisions as to impede and delay payments and jeopardize the ability of contractors to obtain bank financing and performance bonds.

Witnesses for the Department of Defense and the General Services Administration testified to the following effect: The disputes clause provides a mechanism whereby daily on-the-spot decisions can be made readily and finally without fear that decisions in favor of the contractor will be overruled by some higher authority. The Department of Defense has established through ASBCA a highly workable method of administrative review, which provides expeditious, expert, and inexpensive relief after a fair hearing before an independent and impartial administrative tribunal of a judicial character without the cost of litigation. Generally speaking contractors are satisfied with the ASBCA procedure. The Wunderlich decision was unsatisfactory both to the government and to contractors, as a result of which the disputes clause was modified to overcome the effect of such decision. To say that the government acts as judge and jury under the disputes procedure confuses the issue, as the government is more than one person and includes the courts and Congress. A Department of Defense witness stated that the Department is concerned with the time and expense of successive reviews and that it is questionable whether the Department would be willing to incur the expense of an administrative appeal if the finality of administrative appeals were substantially reduced..$^{141}$

The Department of Justice opposed inclusion in the legislation of the words "arbitrary" and "capricious," stating: "We know from long experience that the ${ }^{140 a} 60$ Stat. 237 (I946), 50 U.S.C. \$ roor et seq. (I958).

${ }^{141}$ House Hearings, supra note 92, at 53-54. 
Court of Claims will construe these terms to mean that it could substitute its judgment for that of the head of the department in any case it felt so inclined."142

After the conclusion of the House Judiciary Committee hearings in July r953 there were conferences between interested industry and government groups in an effort to reach a common understanding, which produced a draft of a bill that had the support or acquiescence of all interested groups. The substitute draft bill was presented to Congress by a letter from the Comptroller General dated December 30, I953. Further hearings by the House Judiciary Committee on January 21-22, I954 did not produce any opposition to the substitute draft, and it was adopted by the Judiciary Committee as a substitute for S. 24, Eighty-third Congress, and was enacted into law without any further change, except for the insertion of the words "in any suit now filed or to be filed," so as to make the act retroactive. ${ }^{143}$

S. 24 had made the specified finality standards applicable to "any decision of an administrative official, representative or board," which language was broad enough to include a decision by a contracting officer, whether or not a timely appeal had been taken from such decision. The adopted substitute bill changed the quoted words to read: "any decision of the head of any department or agency or his duly authorized representative or board," thus making the Wunderlich Act standards inapplicable to the decision of a contracting officer and applicable only to the decision of the department head or his representative or board. Concerning this change in applicability of the finality standards, the House Judiciary Committee report on the bill stated:

Under the terms of the standard disputes clause the decision of a contracting officer is final unless the contractor appeals within 30 days. The Supreme Court in United States v. Holpuch Co. (328 U.S. 234), has held that unless a contractor pursues the administrative remedy of appeal to the head of the department which he is granted by the disputes clause, he loses his right to sue in the Court of Claims. Government contractors who have not appealed their decisions to the head of the department within the 30-day period will not be permitted to do so..$^{144}$

How far the Supreme Court has gone in according finality to a contracting officer's decision when the contractor did not file a timely notice of appeal is shown, not only by Holpuch cited in the report of the Judiciary Committee, but even more strongly by United States $v$. Blair, ${ }^{145}$ where the Supreme Court held that the contractor was bound by a contracting officer's decision from which he did not appeal, in the face of findings that the government superintendent at the job site made false reports about the contractor and made numerous rulings in bad faith to punish the contractor for appealing to the contracting officer, and that the contracting officer, when informed of the situation, said that there was practically nothing he

${ }^{142}$ Senate Hearings, supra note 138 , at 19.

${ }^{143}$ roo Cong. Rec. 3674,5510 , 5710 (1954); House Hearings, supra note 92, at 136; H.R. REp. No. $1380,83 \mathrm{~d}$ Cong., $2 \mathrm{~d}$ Sess. (1954).

14H.R. Rep. No. 1380, 83d Cong., 2d Sess. 6 (r954).

${ }^{145} 321$ U.S. 730 (1944). 
could do about it and the contractor "would just have to do the best he could to get along," there being no finding, said the Supreme Court "that appeal to the head of the appropriate department or to his authorized representative would have been futile or prejudicial."146

There is no need for a decision of the contracting officer under the disputes clause to be subject to the Wunderlich Act standards, because the contractor can deprive the contracting officer's decision of any and all finality by the simple device of giving a timely notice of appeal. The rules are very strict as to the requirements of a contracting officer's decision which will become "final and conclusive," if no timely appeal is filed; and at the same time the rules are very liberal as to what constitutes an appeal. Almost anything in writing will suffice if it expresses dissatisfaction with the contracting officer's decision and a desire to "go over the head" of the contracting officer. ${ }^{147}$ However, it is reasonably certain that finality would not be given to an unappealed contracting officer's decision, if the contractor was unaware that the decision was tainted with fraud until after the appeal period had expired or if the contractor was under the influence of economic duress until the expiration of the appeal period.

When Department of Defense and General Services Administration witnesses testified at the January r954 hearings on the Comptroller General's substitute draft bill, they pointed out that it went beyond restoring the pre-Wunderlich rule in that it introduced the substantial evidence test, but stated that they did not oppose the substantial evidence test, which "appears to provide an appellate type of review of the administrative decision."148 One expert doubted the use of the substantial evidence test "where you have neither a full-fledged administrative record for a court to examine, nor a court ... designed to provide appellate review,"149 and expressed the opinion that the substantial evidence rule should not be grafted on the Wunderlich test where administrative appeal boards had not been established. One argument advanced for inclusion of the substantial evidence rule was that it would force government agencies that did not have a hearing procedure comparable with ASBCA to produce their witnesses at a hearing and disclose to the contractor the evidence relied on to support the decision.

The House Judiciary Committee report gives the following explanation of the substantial evidence rule:

The proposed amendment also adopts the additional standard that the administrative decision must be supported by substantial evidence. The requirement that administrative action be supported by substanstial evidence is found in the Administrative Procedure Act. ...

The inclusion of the standard "not supported by substantial evidence" should also

${ }^{210} \mathrm{Id}$. at 736 .

${ }_{147}$ Caskel Forge, Inc., ASBCA No. 7638, I962 BCA 13378 ; Warren Painting Co., ASBCA No. 65II, 6I-2 BCA I 3199; Sahara Waterproofing Co., ASBCA No. 5991, 6I-2 BCA ๆ $3 \mathrm{I} 8 \mathrm{I}$.

${ }^{148}$ House Hearings, supra note 92, at 57.

${ }^{100}$ Id. at IIg. 
correct another condition arising out of the lack of uniformity between the various departments and agencies concerned in the appellate hearing procedures under the disputes clause. It has been brought to light in public hearings that it is the exception rather than the rule that contractors in the presentation of their disputes are afforded an opportunity to become acquainted with the evidence in support of the government's position. It is believed that if the standard of substantial evidence is adopted this condition will be corrected and that the records of hearing officers will hereafter contain all of the testimony and evidence upon which they have relied in making their decisions. It would not be possible to justify the retention of the finality clauses in Government contracts unless the hearing procedures were conducted in such a way as to require each party to present openly its side of the controversy and afford an opportunity of rebuttal. ${ }^{150}$

\section{E. Judicial Application of the Substantial Evidence Rule}

The first case in which the Court of Claims was called on to interpret the substantial evidence rule of the Wunderlich Act was Volentine \& Littleton $v$. United States, ${ }^{151}$ in which the court in an opinion written by Judge Madden refused the government's request that it apply the Wunderlich Act finality tests on the basis of the administrative record and ruled that it would apply such tests, including the substantial evidence rule, on the basis of the entire record, including the evidence on the merits presented to the court by the plaintiff.

In several cases the United States district and circuit courts of appeal reached results contrary to Volentine \& Littleton, holding that whether the decision under the disputes clause was supported by substantial evidence must be determined from an examination of the administrative record. ${ }^{152}$ This conflict between the Court of Claims and the other courts was resolved when the Supreme Court granted certiorari from the Court of Claims decision in Carlo Bianchi \& Co. v. United States. ${ }^{153}$

Bianchi involved a Corps of Engineers civil works contract for the construction of a dam which required the contractor to blast a tunnel through rock. The contractor made claim for the extra expense of installing steel ribs and liner plate to prevent cave-in during construction. The contracting officer allowed the contractor to follow such method of performance, but refused to pay for it as extra work. The ultimate issue was whether the steel ribs and liner plate were made necessary by a "changed condition" so as to be compensable under the contract. Upon appeal, the Engineer Board, after giving the contractor a hearing with an opportunity to present evidence, denied the appeal. Some six years after the Engineer Board decision the contractor filed suit in the Court of Claims. Although the con-

${ }^{150}$ H.R. Rep. No. 1380, 83d Cong., 2d Sess. 4-5 (1954).

${ }_{151} 136 \mathrm{Ct}$. Cl. 638 (1956).

152 Allied Paint \& Color Works v. United States, 309 F.2d x33 (2d Cir. I962); Lowell O. West Lumber Sales v. United States, 270 F.2d 12 (9th Cir. 1959); Wells \& Wells, Inc. v. United States, 269 F.2d 412 (8th Cir. 1959). For citations and discussion of other cases, see Harrison, Eight Years After Wunderlich-Confusion in the Courts: Judicial Review of Decisions by Government Contract Appeals Board, 28 GEO. WASH. L. REv. 56I (I960).

${ }^{153}$ I 44 Ct. Cl. 500 (1959). 
tractor had presented only four witnesses before the Engineer Board, it presented fifteen witnesses at the Court of Claims trial; and the additional witnesses included some outstanding experts who gave evidence showing that, contrary to what was represented by the government specifications, the rock encountered was "weathered," making it susceptible to cave-in, which meant that it was a changed condition entitling the contractor to a price adjustment. If the decision were based on the administrative record, the conclusion would have to be that there was no proof of changed condition entitling the contractor to a price increase, because of the contractor's failure to put in the administrative record the expert testimony showing that the rock was different from what was represented. However, the additional evidence presented to the Court of Claims established to the court's satisfaction the contractor's entitlement to a price increase. The Court of Claims held on the basis of the entire record before it that the Engineer Board decision was not supported by substantial evidence.

In Carlo Bianchi \& Co. v. United States, ${ }^{154}$ the Supreme Court reversed the Court of Claims holding that whether the departmental decision under the disputes clause was supported by substantial evidence "must rest solely on consideration of the record before the department."155 If the court had done no more than this, it seems likely that the decision would have been unanimous. However, the dissenting opinion brought out some serious deficiencies in the procedures of the Engineer Board when it decided the Bianchi appeal. ${ }^{156}$ The Engineer Board rendered its decision only about two years after the Board was established, at which time some of its members were not lawyers, and it had considered evidence not in the record which the appellant had not had an opportunity to refute. The dissenters were of the opinion that this alone was sufficient for a holding that the Engineer Board decision was "arbitrary and capricious" so as to be denied finality. They pointed out that it was necessary to go outside the administrative record to discover the circumstances making the decision arbitrary and capricious. They dissented from the majority opinion that, apart from fraud, it was improper to go outside the administrative record in applying the Wunderlich Act standards, taking the position that a court should be able to go outside of the administrative record to determine whether the administrative decision was "arbitrary and capricious."

In a sense this whole article is background for the issues and controversies which have been raised by the Supreme Court's decision in Bianchi. Since Bianchi is the subject of a separate article in this symposium, the author will conclude with a few brief remarks about the case.

When a case has been tried de novo by a court, it is natural for a judge with a love of justice to want to decide the case "right" in accordance with the evidence before him and to strive to find a way to avoid being bound by a previous decision that he thinks was wrong based on incomplete evidence. To use the words of the

\footnotetext{
${ }_{104} 373$ U.S. 709 ( 1963 ).

${ }^{165} I d$. at 714 .

${ }^{150}$ Id. at 719-20.
} 
Supreme Court, neither side should be "free to withhold evidence at the administrative level and then introduce it in a judicial proceeding."157 It is doubtful that the government will be willing to bear the expense of giving contractors two trials de novo. Bianchi points up the importance of proceedings under the disputes clause that are not subject to the characterization of "subnormal administrative procedures."158 While it has not been shown that ASBCA's lack of subpoena power has had any serious effect on its ability to obtain all pertinent evidence needed for making a correct decision, undoubtedly contractors and their attorneys would have greater confidence in its procedures, if it were given subpoena power and other powers exercised by those agencies coming under the Administrative Procedure Act. ${ }^{159}$

${ }^{167} \mathrm{Id}$. at 717 .

${ }^{158} \mathrm{Id}$. at $72 \mathrm{I}$.

${ }^{150} 60$ Stat. 237 (1946), 5 U.S.C. $\S \S$ Ioor-I0II (I958). 